\title{
Diet, physical activity, and television viewing in relation to the body weight status of West Virginia adolescents
}

\author{
Kimberly M. Morris \\ West Virginia University
}

Follow this and additional works at: https://researchrepository.wvu.edu/etd

\section{Recommended Citation}

Morris, Kimberly M., "Diet, physical activity, and television viewing in relation to the body weight status of West Virginia adolescents" (2004). Graduate Theses, Dissertations, and Problem Reports. 2011. https://researchrepository.wvu.edu/etd/2011

This Thesis is protected by copyright and/or related rights. It has been brought to you by the The Research Repository @ WVU with permission from the rights-holder(s). You are free to use this Thesis in any way that is permitted by the copyright and related rights legislation that applies to your use. For other uses you must obtain permission from the rights-holder(s) directly, unless additional rights are indicated by a Creative Commons license in the record and/ or on the work itself. This Thesis has been accepted for inclusion in WVU Graduate Theses, Dissertations, and Problem Reports collection by an authorized administrator of The Research Repository @ WVU. For more information, please contact researchrepository@mail.wvu.edu. 


\author{
Kimberly M. Morris
}

\author{
Thesis submitted to the \\ College of Agriculture and Forestry \\ at West Virginia University \\ in partial fulfillment of the requirements \\ for the degree of
}

\author{
Master of Science \\ in \\ Human Nutrition and Foods
}
Debra Krummel, Ph.D., R.D., L.D., Chair
Cindy Fitch, Ph.D., R.D., L.D.
Betty Forbes, M.A., R.D., L.D.

Division of Family and Consumer Sciences

\author{
Morgantown, West Virginia \\ 2004
}

Keywords: West Virginia, adolescents, body mass index, diet, physical activity

Copyright 2004 Kimberly M. Morris 


\title{
ABSTRACT \\ Diet, Physical Activity and Television Viewing in Relation to the Body Weight Status of West Virginia Adolescents
}

\author{
Kimberly M. Morris
}

Context: The obesity epidemic is now threatening youth. Yet little is known regarding the factors associated with adolescent weight status.

Objective: To determine whether dietary intakes, physical activity, and hours spent viewing television are related to the body weight status of West Virginia adolescents.

Design, Setting, and Participants: This descriptive study included survey, diet recall, and body mass index data from 1,036, 14-20 year olds attending West Virginia high schools during the years 2002 to 2003.

Results: Overweight students consumed less kilocalories $(\sim 378)(\mathrm{P}<.001)$, less servings of total grains $(\mathrm{P}<.01)$ and a greater percentage of their energy from protein $(\mathrm{P}$ $=.01$ ). A significantly less amount of overweight students reported participating in strengthening/toning physical activities on three or more days of the week $(\mathrm{P}<.01)$.

Conclusion: Overweight adolescents within the state of West Virginia appear more likely to restrict their energy intake rather than exercise to lose weight. Thus, public health intervention strategies to help these students reach a healthy weight while maintaining adequate nutrition are imperative. 


\section{ACKNOWLEDGEMENTS}

First and foremost, I would like to thank Dr. Debra Krummel for her time, expertise, enthusiasm and ability to make this study possible.

To all my committee members: Dr. Krummel, Dr. Cindy Fitch and Ms. Betty Forbes, I would like to extend my deepest appreciation for their time, support, flexibility and patience.

To the entire WVEATS team: Dr. Debra Krummel, Ph.D, RD, LD; Jennifer L. Farmer, BA; Elizabeth Semmens, BS, RD, LD; Jennifer Jones; Julia Krol and Tiffany Lawrence. Without their countless efforts, this thesis would not be possible.

To Susan Arnold, MS, RD, LD: A special thank you for her time and expert advice.

To Elizabeth Semmens: My deepest gratitude for her genuine care and concern, advice, expertise and willingness to help me on her own time. You're one in a million. And last, but certainly not least...

To my parents, Darlene and TJ Morris: The two greatest people in my world! I attribute all of my accomplishments and successes in life to their invaluable love and support. 
ACKNOWLEDGEMENTS..............................................................ii

LIST OF TABLES....................................................................

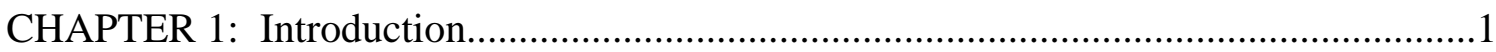

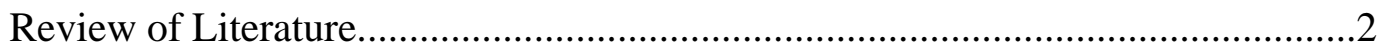

Adolescent Diet..........................................................

Institute of Medicine's DRI Recommendations for US Adolescents........2

Adolescent Physical Activity....................................................

Adolescent Television Viewing..........................................................

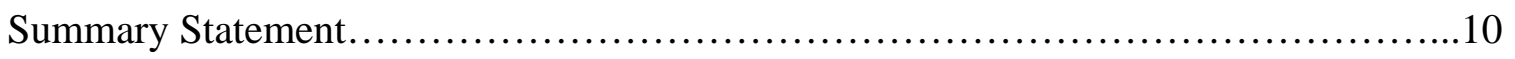

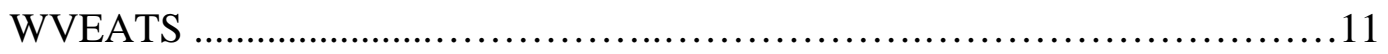

West Virginia Healthy People 2010 Objectives.......................................12

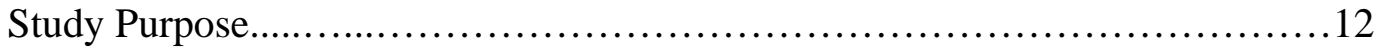

Hypotheses............................................................12

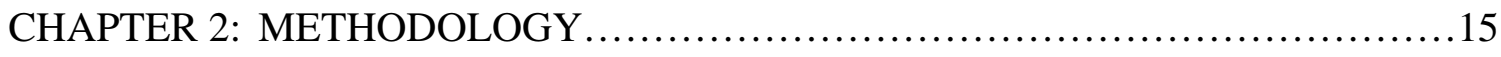

Recruitment Procedures................................................15

WVEATS Sample.......................................................15

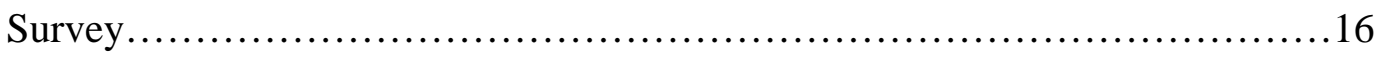

Anthropometrics....................................................... 19

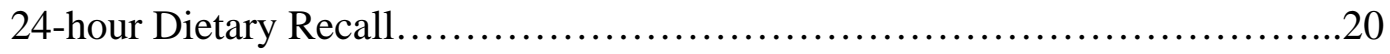

Statistical Analysis.....................................................21

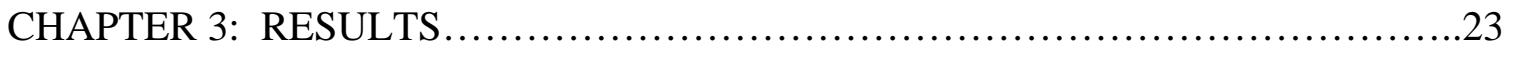

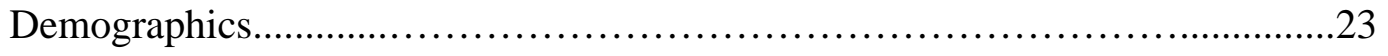


Weight Characteristics......................................................24

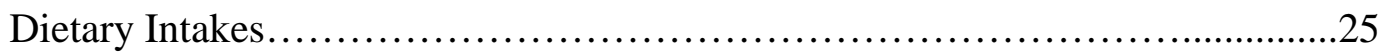

Energy, Nutrient and Fiber Intakes by Weight Status........................27

Food Group and Breakfast Intake by Weight Status..........................30

Physical Activity and Television Viewing.....................................31

CHAPTER 4: DISCUSSION................................................

Energy, Nutrient and Fiber Intake........................................34

Grain, Fruit, Vegetable and Breakfast Intake.............................35

Physical Activity.......................................................36

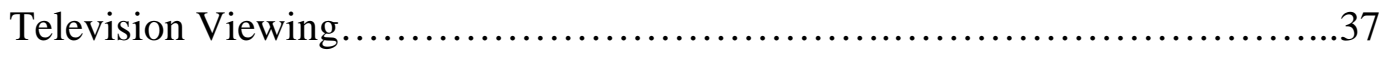

\section{CHAPTER 5: SUMMARY AND CONCLUSIONS}

Summary of Findings................................................38

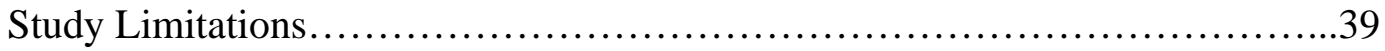

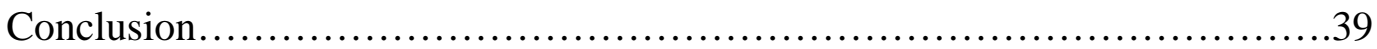

REFERENCES............................................................40

APPENDICES................................................................. 44

Appendix A: Recruitment Letters $\ldots \ldots \ldots \ldots \ldots \ldots \ldots \ldots \ldots \ldots \ldots \ldots \ldots \ldots \ldots \ldots . . \ldots 45$

Appendix B: WVEATS Survey.....................................5 54

Appendix C: CDC Growth Charts......................................65

Appendix D: NIH Human Study Certificate.................................................68

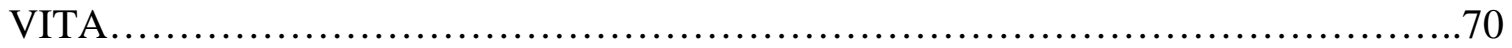




\section{LIST OF TABLES}

Page

TABLE 1: Institute of Medicine’s Dietary Reference Intakes for Adolescents...........2

TABLE 2: West Virginia Healthy People 2010 Objectives.........................12

TABLE 3: Counties and Schools Participating in WVEATS........................................16

TABLE 4: Sample Demographics....................................................................23

TABLE 5: Proportion of WVEATS and NHANES (1999-2000) Adolescents who are 'At-risk for Overweight' and/or Overweight......................................24

TABLE 6: BMI Characteristics of WVEATS ...................................25

TABLE 7: WVEATS Adjusted Median Intakes Compared to NHANES (1999-2000) and

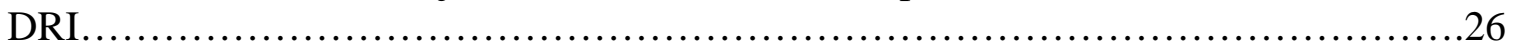

TABLE 8: Percent of WVEATS Males and Females Not Meeting the EAR for Adjusted Nutrients by Body Weight Status..............................................................................27

TABLE 9: Adolescent Adjusted Nutrient Intakes by Body Weight Status.....................29

TABLE 10: Proportion of Adolescent Consuming Grains, Fruits, Vegetables, and

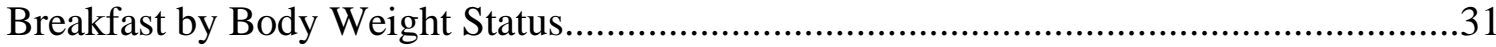

TABLE 11: Proportion of Adolescents Exercising and Viewing Television by Body Weight Status 


\section{CHAPTER 1}

\section{INTRODUCTION}

Adolescents are in a period of their life involving rapid changes in their growth and development. At a time when physiological, biological, psychosocial, social, and cognitive factors impact adolescent behaviors (1), this stage of growth has been identified as a particularly critical phase of growth possibly associated with an increased risk for the development of obesity (2). Not only does adolescent obesity persist into adulthood (3) but it is also independently associated with several risk factors related to cardiovascular disease (4). For example, Must and associates found that over half of the participants who were overweight during adolescence (13-18 years old) became overweight adults (3) and Freedman and colleges found that overweight 5-17 year olds are two times more likely to have high total cholesterol and elevated blood pressure, seven times more likely to have high levels of triglycerides, and 12 times more likely to have high fasting insulin levels when compared to normal weight adolescents (4). These related health risks are alarming when considering the growing numbers of overweight youth in the United States.

Figures from the National Health and Nutrition Examination Surveys (NHANES) have shown that the number of overweight youth has tripled over the past 40 years (5). Their latest estimates revealed that 16 percent of 12-19 year olds were overweight in 1999-2000 (6). National data from the 2001 self-reported Youth Risk Behavior Surveillance (YRBS) survey found that approximately 14 percent of $9^{\text {th }}-12^{\text {th }}$ graders were at risk for becoming overweight and that $11 \%$ were overweight (7). In addition, latest information from the 1999 YRBS state survey revealed that 35 percent of West 
Virginia $9^{\text {th }}-12^{\text {th }}$ graders viewed themselves as overweight (8). Undoubtedly, these data reveal the need to explore the dietary intakes and physical activity levels of adolescents.

\section{REVIEW OF LITERATURE}

\section{Adolescent Diet}

Optimal nutrient intake is necessary for the rapid growth and development of youth. However, many adolescents in the United States may not consume recommended dietary reference intakes (DRI) (9) established by the Institute of Medicine (IOM) (Table 1). Of particular concern are adolescent dietary intakes of sodium, saturated fat, and calcium. For example, data from the National Health and Nutrition Examination Survey (NHANES 1999-2000) revealed that median intakes of saturated fat ( 11\% of kcal) and sodium (3,120 mg) for 12-19 year olds were above the IOM reference intakes for this age group and dietary intakes of calcium (787 mg) were below recommended intakes (9). In addition, several adolescents appear to consume inadequate servings from several food groups including grains, fruits, and dairy $(10,11,12)$. Inadequate consumption of these food groups has been found to promote inadequate nutrient consumption (10).

TABLE 1 Institute of Medicine Dietary Reference Intakes for Adolescents 14-18 years old $(13,14,15,16)$.

\begin{tabular}{|l|l|l|l|l|l|l|l|l|l|l|}
\hline Nutrient & CHO & PRO & FAT & SFA & Sodium & Dietary & Folate & Vitamin & Iron & Calcium \\
Requirement & $\%$ kcal & \% kcal & \% kcal & \% kcal & gm AI & Fiber & ug & C mg & mg & mg \\
\hline Males & $45-65$ & $10-30$ & $25-53$ & - & 1.5 & 38 & 400 & 75 & 11 & 1,300 \\
\hline Female & $45-65$ & $10-30$ & $25-35$ & - & 1.5 & 26 & 400 & 65 & 15 & 1,300 \\
\hline
\end{tabular}


To help promote adequate nutrient consumption, The United States Department of Agriculture suggests that all healthy individuals over the age of two consume six to nine servings of grains (at least three whole grains), three to five servings of vegetables, two to four servings of fruits, and two to three servings of dairy each day. However, national data suggest that many adolescents do not meet these recommended guidelines $(8,10)$. In 1989-1991, the Continuing Surveys of Food Intakes by Individuals (CSFII) (now part of NHANESIU) found that only 1 percent of 12-19 year olds in the United States were meeting the recommended servings suggested for all grain, vegetable, fruit, dairy, and meat groups (10). Consequently, youth who did not meet recommend food group intakes also did not meet recommended dietary allowances (RDAs) for certain micronutrients. In addition, the 1999 YRBS found that less than one quarter of United States and West Virginia youth reported consuming five or more servings of fruits and vegetables over the past seven days or consuming $\geq 3$ glasses of milk daily over the past seven days (8).

Common dietary patterns of adolescents in the United States include excessive intakes of saturated fat and sodium and below recommended intakes of fruits, vegetables, and dairy products $(9,10)$. The reported food consumption patterns of many youth may put them at risk for inadequate nutrient consumption (10). National data on youth have clearly shown that the prevalence of overweight adolescents is growing. Therefore, the need to examine the dietary intakes of this population is apparent.

\section{Adolescent Diet and Weight Status}

Although one particular study conducted in Brazil found that adolescent weight status was not related to measured dietary intakes (17), several studies conducted within the United States suggest otherwise $(11,18,19,20)$. The first aforementioned study 
administered a self-reported, semi-quantitative, food frequency questionnaire to a sample of 12-17 year old males and females in the city of Rio De Janeiro and discovered that normal and overweight (BMI $\geq 90^{\text {th }}$ percentile) adolescents had comparable diets, irrespective of their weight status. Both normal and overweight youth had below recommended intakes of food groups and higher than recommended intakes of foods described as "high-density". Although, it is unknown whether researchers controlled for gender differences in caloric intake, the results suggest that both normal and overweight adolescents in Brazil do not meet recommended dietary guidelines and that all youth in this population may benefit from nutrition education.

On the other hand, similar types of studies conducted within the United States support a link between adolescent diet and weight status. Data collected on a large sample of youth attending public schools from four U.S. states (California, Louisiana, Minnesota, and Texas) found that adolescent food consumption patterns were related to body weight (18). Researchers used a cross-sectional design and the same 24-hour dietary recall method used in this study to compare the dietary intakes of 2,075 13-16 year olds to their BMI status. Overweight youth $\left(\mathrm{BMI}>85^{\text {th }}\right.$ percentile) were more likely to underreport energy (-68 kilocalories), total carbohydrate, sugar, protein, fat, saturated fat, and breakfast intakes. Overweight adolescents were also more likely to report higher intakes of sodium-rich foods compared to normal weight youth ( $\mathrm{p}<.0002)$. Dietary intakes by body weight status remained significantly different even after controlling for sex, race/ethnicity, meal/snack, and number of eating occasions. Similarly, other studies have shown that overweight adolescent are less likely to report consuming dietary fiber (19), calcium (20), fruit (11), and breakfast (18) compared to normal weight adolescents. 
Steffen and colleagues found that a lower body weight status in youth may be associated with dietary fiber intake through whole grain consumption (19). This descriptive study measured the whole grain food intakes of 285 Minnesota students at age 13 and at age 15 using a 127-item food-frequency questionnaire. Overall, students who reported consuming less than one serving of whole grain foods a day (defined as $\geq 25$ percent of product weight whole grain or bran) had a higher mean BMI value than students who consumed over one serving of whole grains per day $(\mathrm{P}=0.05)$. Not only did researchers find that whole grain intake was positively associated with a leaner weight status, but that whole grain intake was positively associated with adolescent fruit, vegetable, fiber, iron, folate, and calcium intake.

Likewise, another cross-sectional study found that dairy intake was negatively associated with adolescent female weight status (20). This study administered a food frequency questionnaire to 36,284 Minnesota students in the $7^{\text {th }}$ through $12^{\text {th }}$ grades to measure their dairy intake through frequency of reported cheese, yogurt, ice cream and milk consumption. Inadequate dairy intake was defined as "never/hardly ever" consuming calcium-rich foods on a daily basis. This study found that females were more likely to consume inadequate amounts of dairy $(\mathrm{P}<.00001)$ and that a higher BMI among this group was associated with a decrease in dairy intake $\left(\mathrm{x}^{2}=15.9, \mathrm{P}=.00001\right)$.

A similar cross-sectional design from the University of Minnesota (11) discovered that youth body weight status may be related to fruit but not vegetable consumption. As part of the Minnesota Adolescent Health Survey, the diets of $36,2847^{\text {th }}-12^{\text {th }}$ graders with a mean age of 15 were measured using a self-reported food frequency questionnaire with 10 items from the YRBS. Weight was compared to dietary intakes using a BMI value for 
overweight which was defined as greater than or equal to 23.8. The chosen reference value is equivalent to a BMI of greater than or equal to the $70^{\text {th }}$ percentile for 15 year old females, according to NHANES. For both adolescent males and females, weight status was negatively associated with fruit (OR: 1.20; CI: 1.13-1.29; $\mathrm{p}<0.0001)$ but not vegetable (OR: 1.06; CI: 0.99-1.13) consumption. In addition, dieting, defined as "changing the way you eat to lose weight five or more times a year”, was associated with inadequate fruit but not vegetable intake. This research further suggests that overweight adolescents may selectively restrict their consumption of foods to lose weight.

There is also some evidence to suggest that inadequate breakfast consumption and adolescent body weight may be related (18). In this study, the diets of 2,075 eighth grade students from the Child and Adolescent Trial for Cardiovascular Health cohort (CATCH) were analyzed using a 24-hour recall method. Meal and snack intakes were compared to body mass index calculated from actual heights and weights. Overweight youth (BMI > $85^{\text {th }}$ percentile) were less likely to self-report consuming breakfast $(p=.0004)$ and less likely to report consuming more than two meals per day than were normal weight youth. Furthermore, meal skipping among adolescents was associated with a decreased consumption in overall nutrient $(\mathrm{p} \leq .0001)$, total energy, total carbohydrate, and percent of energy from sugar. This data suggests that a higher BMI may be associated with inadequate breakfast consumption. Furthermore, this data supports the idea that overweight youth may restrict meal intake in order to restrict their calorie intake.

Although excessive energy consumption can positively impact weight status, current research reveals that overweight adolescents tend to report consuming less total energy when compared to their normal weight counterparts (18). The lower reported 
food intakes of overweight youth may imply that other confounding variables such as dieting, misreporting and/or physical activity may be related factors.

\section{Adolescent Physical Activity}

Participation in regular physical activity is known to prevent many of chronic diseases. In 1996, the Surgeon General stated that moderate to intense levels of physical activity three or more times per week can help reduce the risk of developing Type 2 diabetes mellitus, hypertension, colon cancer, and cardiovascular diseases and recommends that all individuals over the age of two years receive a minimum of 30 minutes of moderate physical activity on most, if not all, days of the week and participate in strength training exercises at least twice a week (21). However, national data from the Youth Risk Behavior Surveillance (YRBS) survey reveals that a number of youth in the United States are not meeting these recommendations (7).

In 2001, only a little over half of U.S. youth reported participating in 20 minute bouts of vigorous physical activity (64\%) or reported participating in strengthening/toning exercises on at least 3 of the last 7 days (53\%) and only one quarter

of these youth reported participating in 30 minute bouts of moderately intense exercise on at least 5 of the last 7 days (7). Additional YRBS survey data have shown that many youth in the United States do not attend physical education classes during the average school week and many are not involved in sports teams. Slightly more than half of all youth sampled in 2001 reported attending PE class on at least one day during the average school week (51.7\%) or participating in one or more team sports over the past 12 months (55.2\%) (7). In addition, youth in the state of West Virginia (38.2\%) have reported much lower levels of PE attendance when compared to United States youth (56.1\%) (8). These 
data are concerning because they imply that youth in the United States may not get enough exercise.

Although there is much research to support the health benefits of physical activity, many youth in the United States and West Virginia do not appear to receive adequate amounts. Lack of physical activity and a growing number of obese youth in the United States are of national concern. The ramifications of persistent obesity will be costly. Therefore, exploring relationships that may impact the weight status of youth are imperative.

\section{Adolescent Physical Activity and Weight Status}

Levin and colleagues (22) examined a sample of 13,295 youth using 1999 YRBS data to determine if there was an association between five types of physical activity (vigorously-intense, moderately-intense, strength training, school PE attendance, and participation in team sports) and the body weight status of youth attending high school. Overweight males (BMI $\geq 95^{\text {th }}$ percentile) were less likely to report participating in physical activity when compared to normal weight youth males $\left(\mathrm{BMI}=15^{\text {th }}-85^{\text {th }}\right.$ percentile). It was concluded that youth weight status appears to be a factor for moderately intense and strengthening types of physical activities in youth males and for participation in team sports in youth females.

In addition, a decrease in team sports participation for overweight youth was noted in a similar study (23). This cross-sectional study of 2,791 8-16 year olds in the U.S. (NHANES 1988-1994) used the same physical activity questions and discovered no significant difference between participation in vigorous physical activity and body weight. However, 8-16 year old males and 14-16 year old females who were overweight 
(BMI $\geq 85^{\text {th }}$ percentile), were less likely to report participating in sports teams when compared to normal weight youth $(\mathrm{p}=<.001)$. Both of the preceding studies found associations between weight status and physical activity, however additional prospective and observational research would help to determine the strength of these relationships.

\section{Adolescent Television Viewing}

The American Academy of Pediatrics recognizes excess television viewing as one of the major types of sedentary activity contributing to obesity of youth in the United States and recommends restricting media time in children to $\leq 2$ hours of "quality" programming a day (24). However, in 1999, almost half of West Virginia youth sampled (42.2\%) had reported viewing three or more hours of television a day on an average school day (8) and in 2001, over one quarter of youth sampled in the United States (38.3\%) reported watching this amount of television (7). Accordingly, the amount of time adolescents spend with activities that promote inactivity should be explored.

\section{Adolescent Television Viewing and Weight Status}

Cross-sectional studies have found a positive relationship between body weight status and inactivity $(23,25)$. Andersen and colleagues (25) utilized NHANES III (19881994) data to determine if youth physical activity levels and the number of hours they spent viewing television correlated to their body weight status. The BMI of 4,063 youth in the United States between the ages of 8-16 were determined by measuring their height and weight. Adolescents had higher BMI values $(\mathrm{p}<.001)$ if they reported viewing 4 or more hours of television a day compared to if they reported viewing no more than 2 hours of television a day. Similarly, researchers who prospectively examined youth BMI values in relation to television viewing (26) discovered a positive "strong-dose response" 
for the relationship between weight status and television viewing. This data collected on 746, 14-21 year olds in 1986 and 1990 from the National Longitudinal Survey of Labor Market Experience found that the odds of being overweight (BMI $\geq 85 \%$ ) increased from two to five times as hours of television viewing increased from 2-3 hours to over five hours per day. Overall, ten to 15 year olds who watched five or more hours of television a day were five times as likely to be overweight (2.2-9.6, 95\% CI) compared to 10-15 year olds who watched two or less hours of television a day. These findings remained conclusive (Odds ratio $=5.3,2.3-12.1,95 \% \mathrm{CI})(\mathrm{p}=$.001) even after controlling for confounding variables i.e. youth and maternal weight status in 1986, income level, family structure, race/ethnicity, and aptitude scores. Furthermore, the time adolescents spent viewing television was the strongest factor influencing their weight status.

Current research is suggesting a positive relationship between levels of inactivity and youth body weight status $(23,25,26,27)$. Noteworthy is the fact that adolescents appear to be spending more time watching television than they do participating in physical activity (28).

\section{Summary Statement}

Over the later part of the $20^{\text {th }}$ century, as the number of overweight youth in the United States significantly increased (5), dietary patterns in this country shifted towards a higher consumption of non-nutritive, energy-dense drinks and snack foods high in sodium (29). In particular, recent data regarding adolescents indicate that many do not meet current recommended dietary guidelines, do not receive enough physical activity, and are likely to spend more time viewing television than being physically active $(8,7)$. It 
is imperative that the lifestyle factors of our youth change in order to reduce the obesity epidemic they face.

\section{WVEATS Study Purpose}

The West Virginia Eating and Activity Teen Survey (WVEATS) was a crosssectional study funded by the West Virginia Bureau for Public Health and conducted by the Department of Community Medicine at West Virginia University School of Medicine. Results from the WVEATS study will be used as baseline data for the West Virginia Healthy People 2010 objectives. West Virginia Healthy People objectives, which are similar to the Healthy People 2010 objectives for the nation, are used for the promotion of health and the reduction of chronic diseases in the state (30). The West Virginia state objectives regarding youth diet, physical activity, and weight status related to this study are summarized in Table 2 . 
TABLE 2 West Virginia Healthy People 2010 Objectives (21 \& 31)

Objective \#

19.6

19.7

19.8

19.10

22.4

\section{Objective}

Increase the proportion of adolescents who consume breakfast daily by $5 \%$ from baseline.

Increase the proportion of adolescents who consume at least five servings of fruits and vegetables per day by $5 \%$ from baseline. Increase the proportion of adolescents who meet dietary recommendations for calcium by $5 \%$ from baseline.

Increase the proportion of adolescents who consume less than $10 \%$ total calories from saturated fat by $5 \%$ from baseline.

Reduce the proportion of children and adolescents who are overweight or obese by $5 \%$ from baseline. Increase to $30 \%$ the proportion of adolescents who engage in moderate physical activity for at least 30 minutes on five or more of the previous seven days from baseline.

\section{Study Purpose}

This sub-study used data collected from the West Virginia Eating and Activity Teen Survey (WVEATS) to determine whether bodyweight was related to nutrient intakes, food group patterns, levels of physical activity, and hours of television viewing in West Virginia adolescents. The following hypotheses were tested:

1. Adolescent dietary intake is not related to body weight status.

A. Adolescent mean caloric intake is not related to body weight status.

B. Adolescent percent of energy from carbohydrate intake is not related to body weight status.

C. Adolescent percent of energy from protein intake is not related to body weight status. 
D. Adolescent percent of energy from total fat intake is not related to body weight status.

E Adolescent percent of energy from saturated fat intake is not related to body weight status.

F. Adolescent mean sodium intake is not related to body weight status.

G. Adolescent mean dietary fiber intake is not related to body weight status.

H. Adolescent mean dietary folate intake is not related to body weight status.

I. Adolescent mean vitamin C intake is not related to body weight status.

J. Adolescent mean iron intake is not related to body weight status.

K. Adolescent mean calcium intake is not related to body weight status.

2. The proportion of adolescents consuming total grains is not related to their body weight status.

3. The proportion of adolescents consuming grains without excessive fat and sugar is not related to their body weight status.

4. The proportion of adolescents consuming fruits is not related to their body weight status.

5. The proportion of adolescents consuming vegetables is not related to their body weight status.

6. The proportion of adolescents consuming breakfast is not related to their body weight status.

7. The proportion of adolescents who are physically active is not related to their body weight status.

A. The proportion of adolescents who participate in at least 20 minutes of vigorous physical activity is not related to their body weight status.

B. The proportion of adolescents who participate in at least 30 minutes of moderately strenuous physical activity is not related to their body weight status.

C. The proportion of adolescents who strengthen or tone their muscles is not related to their body weight status. 
8. The proportion of adolescents who view television on an average school day is not related to their body weight status. 


\section{CHAPTER 2}

\section{METHODOLOGY}

\section{WVEATS Recruitment Procedures:}

WVEATS recruitment and data collection procedures were approved by the West Virginia Institutional Review Board. Student recruitment took place on four levels (See appendix A). a) Contact was made with West Virginia County superintendents (and the Board of Education for one county) for authorization of high school participation in WVEATS; b) High school approval was granted by the school's principal or school's nurse and class recruitment was decided by the school's principal; c) Once teacher approval was obtained, the principal officially approved the WVEATS study in writing; d) Lastly, students from the eligible schools were invited to participate. Both teachers and WVEATS staff recruited whole classrooms to participate during one of the following classes: Physical Education, Health Sciences, Biology, Anatomy, Healthcare Management, Sports Medicine, Family and Consumer Sciences, or Business. In addition, at one school, individual students from their independent research class volunteered to participate. Once required assent and/or consent were obtained from students, appointments were scheduled to visit the school for data collection.

\section{Sample}

The WVEATS sample included a total of 1,092 14-20 year old adolescents attending the $9^{\text {th }}$ through $12^{\text {th }}$ grades in West Virginia. Schools participating in WVEATS included one private and 13 (A-AAA ranked) high schools in five counties. Participating counties and schools and the number of student who completed data for analyses (dietary recalls and anthropometrics) are listed in Table 3. Of 11,362 students 
enrolled (data not shown), 1,300 were available to participate, 1,092 completed surveys (84\% response rate) and 1,036 completed an interview with nutritionist ( $80 \%$ response rate).

\section{TABLE 3. Counties and Schools Participating in WVEATS}

\begin{tabular}{llc}
\hline County/School & Rank & Students Completed (n) \\
\hline Marion County & & \\
Marion Technical Center & $*$ & 8 \\
East Fairmont & AAA & 150 \\
Fairmont Senior & AAA & 183 \\
North Marion & AAA & 103 \\
Kanawha County & & \\
Charleston Catholic & A & 57 \\
Herbert Hoover & AA & 69 \\
Sissonville & AA & 56 \\
Nitro & AAA & 66 \\
Riverside & AAA & 92 \\
Monongalia & & \\
Clay-Battelle & A & 36 \\
Morgantown & AAA & 87 \\
Fayette & & \\
Fayetteville & A & 57 \\
Oak Hill & AA & 3 \\
Taylor & & \\
Grafton & AA & 69 \\
* Not ranked & & $\mathbf{1 , 0 3 6}$ \\
\hline
\end{tabular}

\section{WVEATS Survey}

Either teachers or trained WVEATS staff administered the WVEATS survey to students from eligible high schools. Survey questions (Appendix B) used in this study were developed by the Youth Behavioral Risk Factor Surveillance System (YRBSS) and taken from the Youth Risk Behavior Survey (YRBS) (32). A total of 12 items from the 43 item survey including sample characteristics (four items), physical activity (three 
items) and hours of television viewing (one item) were chosen for analysis. Self-reported demographic information obtained from students included grade in school, gender, race/ethnicity, age, weight, and height.

Three questions related to the levels of adolescent physical activity included: "On how many of the past seven days did you exercise or participate in physical activity for at least 20 minutes that made you sweat or breathe hard, such as basketball, soccer, running, swimming laps, fast bicycling, fast dancing, or similar aerobic activities?”; “On how many of the past seven days did you participate in physical activity for at least 30 minutes that did not make you sweat or breath hard, such as fast walking, slow bicycling, skating, pushing a lawn mower, or mopping floors?”; and “On how many of the past seven days did you do exercises to strengthen or tone your muscles, such as push-ups, sit-ups, or weight lifting?” (32). Students were able to respond from a range of zero to seven days. These three physical activity variables were then categorized into 'zero to two days a week' or 'three to seven days a week'; 'less than five days a week' or 'five or more days a week'; and 'zero to two days a week' or 'three or more days a week, respectively.

Additional physical activity questions were used in the analysis to test for any significant relationships between participation in vigorous, moderate and strength training exercises to PE attendance, time spent exercising in PE and participation in team sports. Students were asked: "In an average week, when you are in school, on how many days do you go to physical education (PE) classes?", "During an average physical education (PE) class, how many minutes do you spend actually exercising or playing sports?” and "During the past 12 months, on how many sports teams did you play? (Include any teams run by your school or community groups)” (32). For PE attendance, students were given 
six choices ranging from zero-five days a week of attendance. For minutes spent exercising during PE, eight possible choices were given ranging from no PE taken to more than 60 minutes. For sports team participation, students were given four response choices ranging from zero to three or more teams. Both PE and sports participation variables were then classified as "yes" if they participated on any days of the week or on any teams or "no" if no PE attendance was recorded during the week or if they reported not participating in any team sports (32).

One question related to level of sedentary behavior was worded, "On an average school day, how many hours do you watch TV?” Students were given seven choices ranging from 'no TV watched' up to 'five or more hours of TV viewing on an average school day' (32). Student responses to TV viewing were categorized as either 'zero to two hours of television watching a day' or 'three or more hours of television watching a day' (32).

In order to understand any differences between nutrient intakes in the sample, an additional question regarding weight management behavior was included in the analysis. This question was worded, "Which of the following are you trying to do about your weight?” Students were given four choices including: trying to lose, gain, stay the same or not trying to do anything about their weight (32). Students who were 'trying to lose weight' were classified as 'dieters' and students who recorded any of the other three response categories were classified as 'non-dieters'. Once survey baseline data were complete, nutritionist were scheduled to visit high schools during class time to measure anthropometrics and conduct the 24-hour dietary recall. After participation, students were eligible to enter a raffle contest for a chance to win a prize. 


\section{Anthropometric Measurements}

Students were measured and weighed following standard protocol from the third National Health and Nutrition Examination Survey (NHANES III) by trained staff (33). Procedures to protect student confidentiality throughout the data collection procedure were maintained. All documents with student information were coded with a participant ID and all anthropometric measurements were obtained in private. In addition, height and weight could only be read by data collectors with a hand-held monitor connected to the scales.

Student height was measured to the nearest $0.1 \mathrm{~cm}$ using a Seca 214 portable stadiometer from Mid-Atlantic Cybex, Charleston. Weight was measured to the nearest 0.01 kilogram (kg) using a Seca 882 scale which could obtain weights up to $200 \mathrm{~kg}$ or 400 lbs. Height and weights were plotted on sex and age specific CDC weight for height, height for age and BMI growth charts $(33,34)$. See Appendix C. Body Mass Index (BMI) was calculated from the formula: weight in kg divided by (height in meters squared) (33). Student BMI values were classified into one of three weight categories. Cut-points for 'at risk for overweight' and overweight adolescents were defined using guidelines from the Centers for Disease Control and Prevention (35). Normal weight was defined as a BMI value below the $85^{\text {th }}$ percentile. 'At risk for overweight' was defined as having a BMI value at or above the $85^{\text {th }}$ and below the $95^{\text {th }}$ percentile. Overweight status was defined as having a BMI at or above the $95^{\text {th }}$ percentile. Underweight adolescents (i.e. BMI $<5^{\text {th }}$ percentile) were included in our normal weight population; they made up less than 2 percent of the total sample. 


\section{Hour Dietary Recall}

Adolescent dietary intakes were collected by a trained nutritionist using a six-step multiple-pass dietary recall method and the Nutrition Data System for Research (NDS_R) software, version 4.05_33. NDS (released in 2002) developed by the Nutrition Coordinating Center (NCC) at the University of Minneapolis, MN. A detailed description of the dietary recall method used has been reported elsewhere (36). In brief, students were asked to recall all food and drink consumed from the previous day, for a consecutive 24 hours starting at midnight through a six-step process. First, students listed all food items consumed and reported the designated meal type and time food item was consumed. Then, nutritionist obtained more detailed information regarding food items reported including amount portion, brand, and preparation method. To help students accurately report portion sizes, visual aids including the Portion Photos of Popular Foods book (37) and measuring tools (cups, spoons etc.) were used. Information from the school's food service director, menus, and recipes provided details students could not provide themselves. Next, the nutritionist reviewed recalled the reported food items back to the student for possible corrections and then reviewed a list of food items most commonly forgotten to report. The use of supplemental vitamin and/or mineral intake was not included in the recall. Student self-reported food items not available with NDS software were presented to the University of Minnesota, Nutrition Coordinating Center in Minneapolis, MN for feedback on appropriate food entry procedures. Thus none of the food items reported by the students were excluded from analysis.

Recalled intakes of grains, fruits, and vegetables were converted into number of servings based on intake in grams divided by the grams per serving listed on the Food 
and Drug Administration (FDA) label (38) with Microsoft Access. Total grains were defined as flour products including whole-grains, baked goods, granola bars, desserts, crackers, pretzels, and tortilla chips. Grains without excessive sugar or fat were more limited and included whole and refined grain products such as yeast breads, cold cereals, rice, pasta, crackers and pretzels but not such food items as baked goods and desserts including cookies, brownies, cake, doughnuts, sweet rolls, etc. Fruits included all canned, dried, fresh, or frozen fruit and 100\% fruit juice (sweetened or unsweetened). Vegetables (including dark green/orange varieties), tomatoes, and legumes but not deep-fat-fried items such as French fries and onions rings, were all counted as vegetable servings for analyses (39). As part of the multiple-pass recall method, students self-determined the type of eating occasion i.e. breakfast, lunch, dinner, or snack. If the type of eating occasion was not designated during recall, the student was then asked to label meal type. All completed food records were included in analyses.

\section{Statistical Analysis}

Frequencies, univariate analysis of variance, and chi-square were conducted on all variables of interest using SPSS for Windows version 11.0. Adolescent energy, nutrient, and dietary fiber intakes were compared between BMI categories using 2-way ANOVA. Nutrient and dietary fiber intakes were adjusted to correct for the significant differences in energy consumption noted between genders (40). In addition, all mean dietary intakes were adjusted to reflect usual intakes (41), correct for individual variability of intakes (42) and to prevent overestimating inadequate intakes of the sample (43). Adjusted nutrient values were obtained using the following formula: Adjusted intake $=[($ subject's mean - group mean) X SD between / SD observed)] + group mean (42). All confidence 
intervals were evaluated at the $95^{\text {th }}$ percentile. Nutrients of interest included energy (kcal), percent of energy from total fat, total carbohydrate, protein, and saturated fat, milligrams of sodium, grams of dietary fiber, micrograms of dietary folate equivalents and milligrams of vitamin C, iron, and calcium.

Student 24-hour recall of total grains, grains without excessive sugar and fat, fruits, vegetables, amount of breakfast consumed and student responses to survey questions pertaining to physical activity and television viewing were classified into dichotomous variables and compared to body weight status using Chi-square. Relationships between variables were considered significant using a P value of $\leq 0.01$. Additional Chi-square analysis were performed to test for significant relationships between dieting behavior and body weight status and to test for significant relationships between levels of physical activity and participation in PE class or participation on team sports. 


\section{CHAPTER 3}

\section{RESULTS}

\section{Sample Demographics}

Shown in Table 4, over half of the total WVEATS sample $(\mathrm{n}=1,092)$ were female, most were 15 years old and in the $9^{\text {th }}$ grade. Sample characteristics were representative of the West Virginia population with 91 percent reporting being of Caucasian decent. Socio-economic characteristics of the sample have been reported elsewhere (36). A total of 1,036 students completed data for analysis.

Table 4. Sample Demographics: gender, age, ethnicity/race, and grade in school

\begin{tabular}{lrr}
\hline & $\mathrm{N}$ & \\
Gender & & $\%$ \\
Females & 676 & 62 \\
Males & 416 & 38 \\
Age (years) & & \\
14 years & 247 & 23 \\
15 years & 490 & 45 \\
16 years & 170 & 16 \\
17 years & 104 & 9 \\
$18+$ years & 80 & 7 \\
Ethnicity & & \\
Caucasian & 997 & 91 \\
Black or African American & 45 & 4 \\
Hispanic or Latino & 11 & 1 \\
Asian & 10 & 0.5 \\
Hawaiian or Pacific Islander & 5 & 0.8 \\
American Indian or Alaskan Native & 9 & 1 \\
Mixed heritage & 15 & \\
Grade in School & & 66 \\
9 & 724 & 14 \\
10 & 147 & \\
11 & 115 & \\
12 & 106 & \\
\hline
\end{tabular}




\section{Sample Weight Status Characteristics}

Table 5 shows the proportion of WVEATS and NHANES (1999-2000) (6) 19-20

year olds who have BMI's $\geq 85^{\text {th }}$ percentile and BMI's $\geq 95^{\text {th }}$ percentile. Overall, the WVEATS sample is slightly more overweight than the NHANES sample. For females, the prevalence of at-risk for overweight and overweight between WVEATS and NHANES (1999-2000) (6) was similar. More WVEATS males were at-risk for overweight and overweight compared to the NHANES male sample.

Table 5. Proportion of WVEATS and NHANES (1999-2000) Adolescents who are Atrisk for Overweight and/or Overweight

\begin{tabular}{|c|c|c|c|c|c|c|}
\hline & \multicolumn{2}{|c|}{ WVEATS } & \multicolumn{4}{|c|}{ NHANES ${ }^{1}$} \\
\hline & Total & Male & Female & Total & Male & Female \\
\hline $\begin{array}{l}\text { At-risk for Overweight }{ }^{2} \& \\
\text { Overweight }^{3}\end{array}$ & $36 \%$ & $40 \%$ & $33 \%$ & $30 \%$ & $31 \%$ & $30 \%$ \\
\hline Overweight $^{3}$ & $20 \%$ & $25 \%$ & $16 \%$ & $16 \%$ & $16 \%$ & $16 \%$ \\
\hline
\end{tabular}

Table adopted from Krummel et al. (36)

${ }^{1}$ Data presented from NHANES (1999-2000) for all races 12-19 years old (6).

${ }^{2} \mathrm{BMI} \geq 85^{\text {th }}$ percentile (35)

${ }^{3} \mathrm{BMI} \geq 95^{\text {th }}$ percentile (35)

Table 6 reveals the body weight status of the sample by gender. Most students were classified as normal weight and slightly more students were classified as overweight compared to 'at risk for overweight'. More females than males were normal weight and more males than females were overweight. The proportion of males and females 'at risk for overweight' was similar. 
Table 6. BMI Characteristics of WVEATS

\begin{tabular}{lccrccc}
\hline Body Mass Index & $\mathrm{n}$ & \% Total & \multicolumn{1}{c}{$\mathrm{n}$} & \% Male & $\mathrm{n}$ & \% Female \\
\hline Normal $^{1}$ & 664 & 64 & 243 & 59 & 421 & 67 \\
At-risk for overweight $^{2}$ & 170 & 16 & 63 & $\sim 15$ & 107 & 17 \\
Overweight $^{3}$ & 202 & 20 & 104 & $\sim 25$ & 98 & 16 \\
\hline
\end{tabular}

Table adopted from Krummel et al. (36)

${ }^{1}$ Normal weight defined as $\mathrm{BMI} \leq 85^{\text {th }}$ percentile

${ }^{2}$ At-risk for overweight defined as BMI between $85^{\text {th }}-94.99^{\text {th }}$ percentile (35)

${ }^{3}$ Overweight defined as BMI $\geq 95^{\text {th }}$ percentile (35)

\section{Dietary Intakes}

WVEATS adjusted median intake and \% meeting EAR for nutrients of interest were previously reported (36). Table 7 illustrates the similar dietary intakes between WVEATS students and the adolescent sub-sample from NHANES (6). Overall, adolescents from both samples consumed comparable amounts of energy, \% energy from protein, carbohydrate, total fat, saturated fat and milligrams of sodium and iron. On the other hand, the WVEATS sample consumed more dietary folate (504 mcg) and calcium (885 mg) compared to NHANES (1999-2000) sample of adolescents (323 mcg and 787 mg respectively). The dietary folate and calcium intake differences between these two groups is thought to be reflective of fortification of these nutrients to a broader variety of foods which occurred after NHANES data collection and before WVEATS data collection periods. 
Table 7. WVEATS Adjusted Median Intakes Compared to NHANES (1999-2000) ${ }^{9}$ and DRI

\begin{tabular}{|c|c|c|c|}
\hline Nutrient & AHNES & WVEATS & \% WVEATS Not Meeting EAR \\
\hline Energy $^{1}$ & 2,129 & $\begin{array}{c}2041.71 \\
(1471.78 ; 2718.18)\end{array}$ & -- \\
\hline$\%$ kcal Protein ${ }^{1}$ & 13.1 & $\begin{array}{c}13.44 \\
(10.88 ; 16.63)\end{array}$ & -- \\
\hline$\%$ kcal CHO ${ }^{1}$ & 54.9 & $\begin{array}{c}55.20 \\
(48.50 ; 62.72)\end{array}$ & -- \\
\hline$\%$ kcal Total Fat ${ }^{1}$ & 132.1 & $\begin{array}{c}31.89 \\
(26.05 ; 37.76)\end{array}$ & -- \\
\hline$\%$ kcal SFA $^{1}$ & 11.3 & $\begin{array}{c}10.87 \\
(8.43 ; 13.72)\end{array}$ & -- \\
\hline Vitamin C (mg) & -- & $\begin{array}{c}59.29 \\
(28.76 ; 128.41)\end{array}$ & 32.5 \\
\hline Folate (mcg) ${ }^{1}$ & 323 & $\begin{array}{c}504.33 \\
(301.18 ; 805.51)\end{array}$ & 29.4 \\
\hline Calcium (mg) $^{1}$ & 787 & $\begin{array}{c}884.65 \\
(547.73 ; 1418.79)\end{array}$ & 70.8 \\
\hline $\operatorname{Iron}(\mathrm{mg})^{1}$ & 13.7 & $\begin{array}{c}13.15 \\
(8.51 ; 19.34)\end{array}$ & 21.0 \\
\hline Sodium (mg) ${ }^{1}$ & 3,120 & $\begin{array}{c}3087.23 \\
(2144.53 ; 4473.66)\end{array}$ & -- \\
\hline
\end{tabular}

Over seventy percent of adolescents did not meet the EAR for calcium intake whereas over half met the EAR for vitamin C, dietary folate, and iron intake. There were no significant differences in the proportion of adolescents who met/did not meet the EAR for vitamin C, dietary folate, calcium, or iron intake by weight status (Table 8). 
Table 8. Percent of WVEATS Not Meeting the EAR for Adjusted Nutrients by Body Weight Status

\begin{tabular}{|c|c|c|c|c|c|c|}
\hline \multicolumn{3}{|c|}{$\begin{array}{c}\% \text { Not Meeting EAR } \\
\end{array}$} & \multirow[b]{2}{*}{$\begin{array}{l}\text { 'At risk for } \\
\text { overweight' }\end{array}$} & \multirow[b]{2}{*}{ Overweight $^{3}$} & \multirow[b]{2}{*}{$\begin{array}{l}\mathbf{P} \\
\text { Value } \\
\end{array}$} & \multirow[b]{2}{*}{$\chi^{2}$} \\
\hline $\begin{array}{l}\text { Nutrient } \\
\text { Nut }\end{array}$ & Total & $\begin{array}{l}\text { Normal } \\
\text { Weight }^{1} \\
\end{array}$ & & & & \\
\hline $\begin{array}{l}\text { Vitamin C } \\
\text { (mg) }\end{array}$ & 32.6 & 32.5 & 36.5 & 29.7 & .380 & 1.93 \\
\hline $\begin{array}{l}\text { Dietary Folate } \\
\text { (mcg) }\end{array}$ & 29.4 & 28.2 & 33.5 & 29.7 & .401 & 1.83 \\
\hline $\begin{array}{l}\text { Calcium } \\
\text { (mg) }\end{array}$ & 70.8 & 68.4 & 76.5 & 73.8 & .071 & 5.30 \\
\hline $\begin{array}{l}\text { Iron } \\
\text { (mg) }\end{array}$ & 21.1 & 20.4 & 23.5 & 21.3 & .668 & .806 \\
\hline
\end{tabular}

\section{Energy, Nutrient, and Fiber Intake by Body Weight Status}

On average, males consumed significantly more calories than females (2,603

versus 1,810, respectively) ( $\mathrm{p}<.001$ ) (data not shown). Differences in energy

consumption between genders were significantly different, irrespective of bodyweight.

For this reason, the covariate adjusted kcal (2217.96) was used when comparing nutrient

and dietary fiber differences in intakes between males and females by body weight status.

Adolescent mean caloric intake was related to body weight status (Table 9).

Therefore, we reject the null hypothesis. Within genders, normal weight students $(\mathrm{BMI}<$ $85^{\text {th }}$ percentile) consumed the most calories and overweight students $\left(\mathrm{BMI} \geq 95^{\text {th }}\right.$

percentile) consumed the least. On average normal weight adolescents consumed $~ 378$

more calories than overweight adolescents. Total energy consumption between normal

and 'at risk for overweight' ( \pm 204 kcal, $\mathrm{P}=.018$ ) and between 'at risk for overweight'

and overweight adolescents $( \pm 174 \mathrm{kcal}, \mathrm{P}=.095)$ were not considered significantly 
different. Although gender and body weight were both related to adolescent energy consumption, only $18 \%$ of the variance could be explained by these two factors alone.

On the other hand, we accept the null hypotheses regarding adolescent percent of energy intake from carbohydrate, total fat, and saturated fat because these macronutrients were not related to body weight status (Table 9). Although body weight, gender, and caloric intake could not explain for differences in adolescent percent energy from carbohydrates, approximately $60 \%$ of the variance in adolescent total fat intake could be explained by caloric intake and gender and over half of the variance in saturated fat intake could be explained by caloric intake alone. In contrast, adolescent percent of energy intake from protein was related to body weight status $(\mathrm{F}=4.67, \mathrm{P}=.010)$. Therefore, we reject the null hypothesis. Both male and female overweight and 'at risk for overweight' students consumed more of their calories from protein than did normal weight students (Table 9). However, gender and BMI only accounted for $32 \%$ of the variance in adolescent protein intake.

Adolescent mean sodium, dietary fiber, dietary folate, vitamin C, iron, and calcium intake were not related to body weight status (Table 9). Therefore, we accept the null hypotheses. Although weight status was not related to nutrient and dietary fiber consumption, over $70 \%$ of the variance in adolescent sodium intake (71\%) and over half of the variance in adolescent dietary fiber consumption (53\%) could be explained by calories alone. In addition, adolescent gender and caloric intake explained over half of the variance in iron consumption (52\%), over forty percent of the variance in calcium intake (42\%), and over one quarter of the variance in dietary folate intake (26\%). 
Table 9. Adolescent Adjusted Dietary Intakes by Body Weight Status

\begin{tabular}{|c|c|c|c|c|}
\hline \multicolumn{5}{|c|}{ Body Weight Status Category } \\
\hline $\begin{array}{l}\text { Mean } \\
\text { Total }\end{array}$ & $\begin{array}{l}\text { Normal } \\
\text { weight }^{1}\end{array}$ & $\begin{array}{l}\text { 'At risk for } \\
\text { overweight" }\end{array}$ & Overweight $^{3}$ & $\begin{array}{l}\mathbf{P} \\
\text { Value }\end{array}$ \\
\hline$(\mathrm{N}=1,034)$ & $(\mathrm{N}=662)$ & $(\mathrm{N}=107)$ & $(\mathrm{N}=202)$ & \\
\hline \multicolumn{5}{|c|}{ Energy (Kilocalories)* } \\
\hline $\begin{array}{l}2206 \pm 38 \\
(2133-2281)\end{array}$ & $\begin{array}{l}2463 \pm 40^{a} \\
(2384-2542)\end{array}$ & $\begin{array}{l}2219^{a, b} \pm 79 \\
(2063-2375)\end{array}$ & $\begin{array}{l}1938^{b} \pm 70 \\
(1800-2077)\end{array}$ & $<.001^{*}$ \\
\hline \multicolumn{5}{|c|}{ Carbohydrate (\% Energy) } \\
\hline $\begin{array}{l}55 \pm .41 \\
(54-56)\end{array}$ & $\begin{array}{l}56 \pm .45 \\
(55-57)\end{array}$ & $\begin{array}{l}55 \pm .87 \\
(53-56)\end{array}$ & $\begin{array}{l}54 \pm .77 \\
(52-55)\end{array}$ & .040 \\
\hline \multicolumn{5}{|l|}{ Protein (\% Energy)* } \\
\hline $\begin{array}{l}14.4 \pm .17 \\
(14.1-14.7)\end{array}$ & $\begin{array}{l}13.8 \pm .19 \\
(13.4-14.2)\end{array}$ & $\begin{array}{l}14.6 \pm .36 \\
(13.9-15.3)\end{array}$ & $\begin{array}{l}14.8 \pm .32 \\
(14.2-15.5)\end{array}$ & $.010^{*}$ \\
\hline \multicolumn{5}{|l|}{ Total Fat (\% Energy) } \\
\hline $\begin{array}{l}31.9 \pm .33 \\
(31.3-32.5)\end{array}$ & $\begin{array}{l}31.6 \pm .36 \\
(30.9-32.3)\end{array}$ & $\begin{array}{l}31.9 \pm .69 \\
(30.7-33.3)\end{array}$ & $\begin{array}{l}32.1 \pm .61 \\
(30.9-33.3)\end{array}$ & .755 \\
\hline \multicolumn{5}{|c|}{ Saturated Fat (\% Energy) } \\
\hline $\begin{array}{l}11.1 \pm .14 \\
(10.9-11.4)\end{array}$ & $\begin{array}{l}11.1 \pm .15 \\
(10.8-11.4)\end{array}$ & $\begin{array}{l}11.2 \pm .30 \\
(10.6-11.7)\end{array}$ & $\begin{array}{l}11.2 \pm .26 \\
(10.7-11.7)\end{array}$ & .907 \\
\hline \multicolumn{5}{|l|}{ Sodium (mg) } \\
\hline $\begin{array}{l}3571 \pm 40.1 \\
(3492-3651)\end{array}$ & $\begin{array}{l}3490 \pm 43.8 \\
(3404-3576)\end{array}$ & $\begin{array}{l}3655 \pm 84.7 \\
(3488-3821)\end{array}$ & $\begin{array}{l}3570 \pm 75.6 \\
(3422-3719)\end{array}$ & .196 \\
\hline \multicolumn{5}{|c|}{ Dietary Fiber ${ }^{4}$ (grams) } \\
\hline $\begin{array}{l}13.6 \pm .22 \\
(13.1-14.1)\end{array}$ & $\begin{array}{l}13.7 \pm .24 \\
(13.2-14.1)\end{array}$ & $\begin{array}{l}13.4 \pm .46 \\
(12.5-14.3)\end{array}$ & $\begin{array}{l}13.6 \pm .41 \\
(12.8-14.4)\end{array}$ & .865 \\
\hline \multicolumn{5}{|c|}{ Dietary Folate Equivalents (mcg) } \\
\hline $\begin{array}{l}664 \pm 26 \\
(613-716)\end{array}$ & $\begin{array}{l}697 \pm 29 \\
(641-753)\end{array}$ & $\begin{array}{l}636 \pm 55 \\
(528-745)\end{array}$ & $\begin{array}{l}660 \pm 49 \\
(563-757)\end{array}$ & .567 \\
\hline \multicolumn{5}{|l|}{ Vitamin C (mg) } \\
\hline $\begin{array}{l}96.2 \pm 4.1 \\
(88.1-104)\end{array}$ & $\begin{array}{l}98.4 \pm 4.5 \\
(89.7-107)\end{array}$ & $\begin{array}{l}91.1 \pm 8.6 \\
(74-108)\end{array}$ & $\begin{array}{l}99.0 \pm 7.7 \\
(83.9-114)\end{array}$ & .733 \\
\hline \multicolumn{5}{|l|}{ Iron (mg) } \\
\hline $\begin{array}{l}15.7 \pm .27 \\
(15.1-16.2)\end{array}$ & $\begin{array}{l}15.8 \pm .30 \\
(15.2-16.4)\end{array}$ & $\begin{array}{l}15.5 \pm .57 \\
(14.4-16.7)\end{array}$ & $\begin{array}{l}15.7 \pm .51 \\
(14.7-16.7)\end{array}$ & .932 \\
\hline \multicolumn{5}{|l|}{ Calcium (mg) } \\
\hline $\begin{array}{l}1131 \pm 26 \\
(1080-1182)\end{array}$ & $\begin{array}{l}1146 \pm 28 \\
(1090-1201)\end{array}$ & $\begin{array}{l}1108 \pm 55 \\
(1001-1215)\end{array}$ & $\begin{array}{l}1140 \pm 49 \\
(1045-1236)\end{array}$ & .827 \\
\hline $\begin{array}{l}{ }^{1} \text { Defined as } \leq 84.99^{\text {th }} \text { pe } \\
{ }^{4} \text { Unadjusted } \\
\pm \text { SE = Standard error of } \\
\text { Parentheses include the } \\
\text { Different superscripts }{ }^{\mathrm{a}} \text {, } \\
\text { Values controlled for cal }\end{array}$ & $\begin{array}{l}\text { lence interval fo } \\
\text { represent statisti } \\
\text { differences note }\end{array}$ & $\begin{array}{l}\text { the mean } \\
\text { l significance beth } \\
\text { between genders: }\end{array}$ & $\begin{array}{c}\text { ween BMI categ } \\
\text { covariate kcal= }\end{array}$ & \\
\hline
\end{tabular}




\section{Food Group and Breakfast Intake by Body Weight Status}

The proportion of normal, 'at risk for overweight' and overweight adolescents consuming total grains was significantly different $\left(X^{2}=12, p>.01\right)$ (Table 10). Therefore, we reject the null hypothesis. Both overweight and 'at risk for overweight' students consumed fewer total grains than normal weight students. On the other hand, adolescent consumption of 'total grains without excessive fat and sugar' was not related to body weight status. Therefore, we accept the null hypothesis. This data also show that a greater proportion of students consumed six or more servings of total grains per day compared to six or more servings of 'grains without added fat and sugar' per day. In addition, we accept the null hypotheses regarding adolescent fruit, vegetable, and breakfast consumption because the proportion of adolescents consuming them was not related to their body weight status. Overall, a greater percentage of students consumed less than two servings of fruit and less than three servings of vegetables within the past 24 hours and slightly over half reported consuming breakfast. 


\begin{tabular}{|c|c|c|c|c|}
\hline \multicolumn{5}{|l|}{$\begin{array}{l}\text { Table 10. Proportion } \\
\text { Breakfast by Body } \\
\end{array}$} \\
\hline & \multicolumn{4}{|c|}{ \% Consumption by Body Weight Status Category } \\
\hline Total \% & $\begin{array}{l}\text { Normal } \\
\text { Weight }^{1}\end{array}$ & $\begin{array}{l}\text { 'At risk for } \\
\text { overweight' }\end{array}$ & Overweight $^{3}$ & $\begin{array}{l}\mathbf{P} \\
\text { Value }\end{array}$ \\
\hline$(\mathrm{N}=1,034)$ & $(\mathrm{N}=662)$ & $(\mathrm{N}=107)$ & $(\mathrm{N}=202)$ & \\
\hline \multicolumn{5}{|l|}{$\begin{array}{l}\text { Total Grains* } \\
(\geq 6 \text { servings per day) }\end{array}$} \\
\hline \multicolumn{5}{|l|}{$\begin{array}{l}\text { Grains without added fat and sugar } \\
\text { ( } \geq 6 \text { servings per day) }\end{array}$} \\
\hline $\begin{array}{l}\text { Total Fruits }{ }^{4} \\
\text { (> } 2 \text { servings per day) }\end{array}$ & $16.2(107)$ & $12.9(22)$ & $9.9(20)$ & .071 \\
\hline \multicolumn{5}{|l|}{$\begin{array}{l}\text { Total Vegetables } \\
\text { ( } \geq 3 \text { servings per day) }\end{array}$} \\
\hline $22.3(231)$ & $23.7(157)$ & $19.4(33)$ & $20.3(41)$ & .359 \\
\hline $\begin{array}{l}\text { Breakfast } \\
\text { (Once within past } 24 \text { hours) } \\
\qquad 66.4(687)\end{array}$ & $68.1(451)$ & $59.4(101)$ & $66.8(135)$ & .099 \\
\hline $\begin{array}{l}\text { Values represent percentages and parenth } \\
{ }^{1} \text { Defined as } \leq 84.99^{\text {th }} \text { percentile, }{ }^{2} \text { Define } \\
{ }^{4} \text { Includes all fruits and fruit juice (sweet } \\
5 \text { Includes all vegetables and tomatoes ex }\end{array}$ & $\begin{array}{l}\text { s include the } \\
\text { s } 85^{\text {th }}-94.99 \\
\text { d or unsweete } \\
\text { t for deep-fat }\end{array}$ & rcentile, ${ }^{3}$ Defined & as $\geq 95^{\text {th }}$ percenti & \\
\hline
\end{tabular}

\section{Physical Activity and Television Viewing by Body Weight Status}

The proportion of adolescents who participated in at least 20 minutes of vigorous physical activity and in at least 30 minutes of moderately strenuous physical activity was not related to their body weight status (Table 11). Thus, we accept the null hypotheses. A greater proportion of students reported participating in vigorous physical activity on three or more rather than two or less of the past seven days and a greater proportion of students reported participating in moderately strenuous physical activity on five or less rather than five or more of the past seven days. On the other hand, the proportion of adolescents who reported strengthening or toning their muscles was related to their body weight status.

Thus, we reject the null hypothesis. A greater proportion of 'at risk for overweight' and 
normal weight students reported strengthening and toning their muscles on three or more rather than two or less of the past seven days whereas a greater proportion of overweight students reported strengthening or toning their muscles on two or less rather than three or more of the past seven days. In addition, a greater proportion of adolescents reported participating in strength training exercises on three or more days rather than two or less days over the past week. Overall, a greater proportion of students reported participating in vigorous physical activity compared with moderately strenuous or strengthening/toning physical activities.

Additional statistical analysis were conducted to see if the amount of physical activity adolescents reported were related to physical education (PE) attendance and team sports participation (data not shown). Except for the comparison made between participation in moderately strenuous physical activity and participation in team sports, the number of days in PE class, the amount of time spent exercising in PE class and participation in team sports were all positively associated with vigorously strenuous, moderately strenuous, and strength training activities $(\mathrm{p}<0.01)$. On the other hand, the proportion of adolescents who view television on an average school day was not related to their body weight status. Therefore, we accept the null hypothesis. A greater proportion of students reported watching television for two or less rather than three or more hours on an average school night (Table 11). 


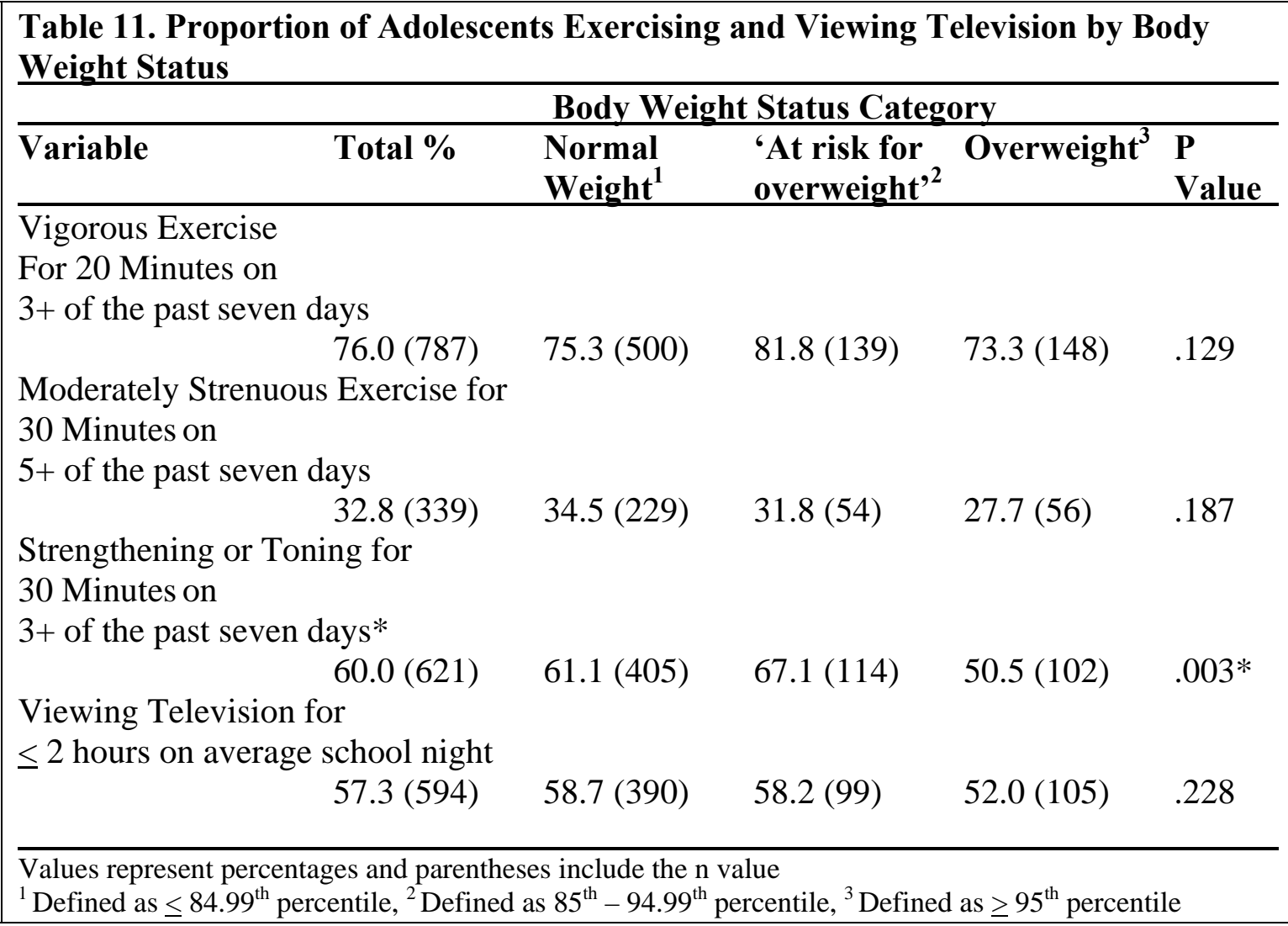




\section{CHAPTER 4 \\ DISCUSSION}

\section{Energy, Nutrient, and Fiber Intakes by Body Weight Status}

Because overweight adolescents reported consuming the least amount of calories and normal weight adolescent reported consuming the most, it is suggested that either overweight students were either underreporting or restricting their caloric intake to lose weight. Indeed, we did find that a greater proportion of overweight students were dieting compared to 'at risk for overweight' and normal weight students.

Because more protein is needed to maintain muscle mass, it was not particularly surprising to find that percent energy intake from protein was positively associated with an increased body mass index. Although, we were not able to determine adolescent gram protein intake by body weight status, others have reported (18) that students with a BMI $\geq 85^{\text {th }}$ percentile consume less protein compared to normal weight adolescents. These differences suggest that other sample characteristics are possibly influencing dietary intakes of the sample of interest. In this study, adolescent weight status was only able to explain for some of the differences in overall adolescent total energy consumption and percent of energy from protein and was not able to explain for differences in adolescent intake of any other nutrient analyzed.

Similar to our study, Dwyer and colleagues (18) found that a sample of eighth grade students from the original CATCH cohort with a BMI greater than or equal to the $85^{\text {th }}$ percentile consumed less kilocalories than normal weight students. However, unlike our study, researchers discovered that overweight students consumed more sodium than normal weight students. Although researchers used the same 24-hour dietary recall 
method and anthropometric measurements to collect data, their sample included students with a much broader set of demographic characteristics and used different statistical analysis procedures; thus direct comparisons to our homogenous sample are difficult.

\section{Grain, Fruit, Vegetable, and Breakfast Intake by Body Weight Status}

It was discovered that overweight adolescents are more likely than normal weight adolescents to restrict their caloric intake of nutrient-dense grain foods. However, because a greater proportion of students from all three weight categories consumed six or more servings of total grains compared to six or more servings of 'total grains without excessive fats or sugars', it is suggested that all students, regardless of weight status, consume more of their energy from caloric-dense rather than nutrient-dense grain foods.

When measuring weight status as a continuous variable, other research (19) has shown an inverse relationship between adolescent whole grain consumption and BMI. Although we did not measure whole grain consumption, used different measurements to interpret weight status and different survey method to collect dietary intakes, our research also indicates that weight status was associated with the type of grain adolescents consumed, with significantly more normal weight than overweight students meeting recommendations for consuming nutrient dense grain foods. Therefore, it appears as if overweight adolescents may restrict their energy intake of certain types of grains foods rather than all grain foods.

On the other hand, whereas we did not, others have reported lower fruit consumption among overweight adolescents (11). Difference in sample characteristics, methods used to measure dietary intakes, or most likely, the use of different cut points and statistical analyses to define and interpret adolescent dietary intakes by weight status 
are possible reasons we were not able to confirm these results. In addition, whereas we did not find a significant relationship between breakfast intake and weight status, others (18) have reported that significantly less adolescents with a BMI greater than or equal to the $85^{\text {th }}$ percentile reported consuming breakfast. Although researchers from this study used similar methods to collect dietary intakes and cut points to determine weight status, characteristics of the two samples were not completely alike. Therefore, confounding factors inherent of the adolescent sample other than weight status may have influenced dietary intake results.

\section{Physical Activity and Body Weight Status}

Similar to our study, Levin and colleagues (22) found that significantly less overweight males reported involvement in strengthening and toning types of physical activities. In addition, both studies revealed that students reported participating in less moderate than vigorous physical activity. One can only guess whether this means adolescents tend to exercise on fewer than five days out of the week or that tend to participate in fewer moderate types of physical activities as described in the survey. In addition, another cross-sectional design by Dowda and colleagues (23) reported that overweight students were less likely to report participating in team sports. Although we did not measure this variable against weight status directly, we did find a significant positive correlation between this type of physical activity and the amount of time students reported being physically active. Similar findings $(22,23)$ regarding larger samples of youth within the United States adds strength to the positive relationship found between physical activities and a lower body weight status. Overall, current data appears to suggest that at least for some types of physical activities (namely strength training and 
team sport participation) overweight adolescents report participating less than their normal weight counterparts.

\section{Television Viewing and Body Weight Status}

The proportion of adolescents who spent viewing three or more hours of television on an average school night among WVEATS adolescents and adolescents from a nationally representative sample (7) were similar. A significant proportion of adolescents reported watching several hours of television during the average school week; therefore if weight status is positively related to television viewing, it may be promising to target this type of activity within obesity intervention strategies (27). Although in this study, three or more hours of television viewing was not significantly related to adolescent body weight status, previously mentioned research has suggested a positive relationship between the two $(23,25,26)$. Two large cross-sectional studies (23, 25) and one prospective study (26) found that adolescents who watched four or more and five or more hours of television a night, respectively, were more likely to have a BMI of greater than or equal to the $85^{\text {th }}$ percentile. Hence, it may be that adolescent television viewing is related to weight status at higher levels than were considered in our study. Another possible explanation may be that the relationship between television viewing and weight status is more strongly influenced by other sample characteristics present within NHANES adolescents $(23,25)$ but that were not present within our sample. 


\section{CHAPTER 5}

\section{SUMMARY AND CONCLUSIONS}

\section{Summary of Findings}

Nearly 20 percent of the WVEATS population is overweight and over 15 percent are 'at risk for overweight'. The sample had similar BMI characteristics as NHANES (1999-2000), except for males who were more 'at risk for overweight’ and overweight than the nationally represented sample. The sample was demographically representative of the West Virginia adolescent population.

Significant differences in dietary intakes between weight statuses were noted for total energy, percent calories from protein and total grain consumption. Decreased total calories and decreased total grain consumption were associated with an increased BMI, whereas percent calories consumed from protein was significantly related with an increased BMI. Reduced energy consumption by overweight adolescents appears related to a restriction in calories rather than underreporting.

Significant differences in physical activity by body weight statuses were noted for strengthening and toning physical activities only. Students 'at risk for overweight' reported strengthening or toning their muscles significantly more often than overweight students. Additional analysis revealed that all three levels of physical activity examined were significantly related to attendance in physical education class, amount of time spent exercising, and participation in team sports. Only time spent participating in strengthening and toning exercises to minutes spent exercising in PE were unrelated. 


\section{Limitations}

This study used a cross-sectional design to describe and make pair-wise comparisons between select adolescent behaviors and body weight status. Although the study design made possible to test for significant relationships, we were not able to prove causality. In addition, the study design only reveals the sample's current characteristics and behaviors and therefore does not account for past or future possible factors that could implicate the data. Thus results should be interpreted with caution.

\section{Conclusion}

We set forth to determine whether or not adolescent dietary intakes, physical activity levels, and television viewing were related to the body weight status of West Virginia adolescents. Whereas overweight adolescent consumption of total energy and total grains and participation in strengthening and toning exercises were significantly lower than that of normal weight students, overweight adolescent percent of energy intake from protein was significantly higher. Thus we rejected the null hypotheses for these variables only. Additional cross-sectional and prospective studies are needed to determine the strengths of these relationships in other populations.

In conclusion, overweight adolescents within the state of West Virginia appear more likely to restrict their energy intake of certain foods rather than exercise to lose weight. Public health intervention strategies to help West Virginia adolescents reach a healthy weight while maintaining proper nutritional intake is evident. 


\section{$\underline{\text { References }}$}

1. Story M, Alton L. Becoming a Woman: Nutrition in Adolescence. In: Krummel DA, Kris-Etherton PM. Nutrition in Women's Health. Gaithersburg, MD: Aspen; 1996:1-33.

2. Dietz W. Critical periods in childhood for the development of obesity. Am J Clin Nutr. 1994;59:955-959.

3. Must A, Jacques PF, Dallal GE, Bajema CJ, Dietz WH. Long term morbidity and mortality of overweight adolescents. N Engl J Med. 1992; 327:1350-1355.

4. Freedman DS, Dietz WH, Srinivasan SR, Berenson GS. The relation of overweight to cardiovascular risk factors among children and adolescents: The Bogalusa Heart Study. Pediatrics. 1999;103(6):1175-1182.

5. Centers for Disease Control and Prevention: National Center for Health Statistics. Prevalence and overweight among children and adolescents: United States, 1999-2000. Available at: http:www.ede.gov/nchs/products/pubs/pubd/hestats/overwght99.htm. Accessed April 25, 2004.

6. Ogden CL, Flegal, KM, Carroll MD, Johnson CL. Prevalence and trends in overweight among US children and adolescents, 1999-2000. JAMA. 2002;288:17281732.

7. Centers for Disease Control and Prevention. Surveillance Summaries, June28, 2002. MMWR 2002:51 (No. SS-4).

8. National Center for Chronic Disease Prevention and Health Promotion; Adolescent and School Health: YRBSS; Youth Risk Behavior Surveillance System. Available at: http://apps.nccd.cdc.gov/YRBSS/CompareTrendV.asp. Accessed September 8, 2003.

9. Wright JD, Wang C, Kennedy-Stephenson J, Ervin RB. Dietary intake of ten key nutrients for public health, United States: 1999-2000. Advance Data from Vital and Health Statistics \{serial online\}. April 2003; issue 334.

10. Munoz KA, Krebs-Smith SM, Ballard-Barbash R, Cleveland LE. Food intakes of US children and adolescents compared with recommendations. Pediatrics. 1997;100:323329.

11. Neumark-Sztainer D, Story M, Resnick MD, Blum, RW. Correlates of inadequate fruit and vegetable consumption among adolescents. Prev Med. 1996;24:497-505.

12. Kant AK. Reported consumption of low-nutrient-density foods by American children and adolescents: Nutritional and health correlates, NHANES III, 1988 to 1994. Arch Pediatr Adolesc Med. 2003;157:789-796. 
13. Institute of Medicine of the National Academies. Food and Nutrition Board. Dietary Reference Intakes Tables: Elements. Available at: http://www.iom.edu/file.asp?id=7294. Accessed on April 30, 2004.

14. Institute of Medicine of the National Academies. Food and Nutrition Board. Dietary Reference Intakes Tables: Macronutrients. Available at: http://www.iom.edu/file.asp?id=7300. Accessed on April 30, 2004.

15. Institute of Medicine of the National Academies. Food and Nutrition Board. Dietary Reference Intakes Tables: Electrolytes and Water. Available at:

http://www.iom.edu/file.asp?id=20004. Accessed on April 30, 2004.

16. Institute of Medicine of the National Academies. Food and Nutrition Board. Dietary Reference Intakes Tables: Vitamins and Minerals. Available at: http://www.iom.edu/file.asp?id=7296. Accessed on April 30, 2004.

17. Andrade RG, Pereira RA, Sichieri R. Food intake in overweight and normal-weight adolescents in the city of Rio de Janeiro. Cad Saude Publica [serial online]. 2003;19(5):1485-95 [Abstract]. Accessed February 28, 2004.

18. Dwyer JT, Evans M, Stone EJ. Adolescents' eating patterns influence their nutrient intakes. J Am Diet Assoc. 2001;101:798-801.

19. Steffen LM, Jacobs DR, Murtaugh MA, Moran A, Steinberger J, Hong C, Sinaiko AR. Whole grain intake is associated with lower body mass and greater insulin sensitivity among adolescents. Am J Epidemiol. 2003;158(3):243-250.

20. Neumark-Sztainer D, Story M, Dixon LB, Resnick MD, Blum RW. Correlates of inadequate consumption of dairy products among adolescents. J Nutr Educ. 1997;29:1220.

21. West Virginia Healthy People 2010 Objectives. Objective 22: Physical activity and fitness. Available at: http://www.wvdhhr.org/bph/hp2010/objective/i.htm. Accessed August 4, 2003.

22. Levin S, Lowry R, Brown D R, Dietz W H. Physical activity and body mass index among US adolescents. Arch Pediatr Adolesc Med. 2003;157:816-820.

23. Dowda M, Ainsworth B E, Addy C L, Saunders R, Riner W. Environmental influences, physical activity, and weigh status in 8-16- Year-Olds. Arch Pediatr Adolesc Med. 2001;155:711-717.

24. American Academy of Pediatrics: Committee on Public Education. Children, adolescents, and television. Pediatrics. 2001; 107(2):423-426. 
25. Andersen RE, Crespo CJ, Bartlett SJ, CheskinLJ, Pratt M. Relationship of physical activity and television watching with body weight and level of fatness among children: Results from the Third National Health and Nutrition Examination Survey. JAMA.1998;279(12):938-942.

26. Gortmaker SL, Must A, Sobol AM, Peterson K, Colditz GA, Dietz WH. Television viewing as a cause of increasing obesity among children in the United States, 1986-1990. Arch Pediatr Adolesc Med.1996;150:356-362.

27. Robinson TN. Reducing children's television viewing to prevent obesity. JAMA.1999;282:1561-1567.

28. Heath GW, Pratt M, Warren C, Kann L. Physical activity patterns in American high school students. Arch Pediatr Adolesc Med. 1994; 148:1131-1136.

29. Nielsen SJ, Siega-Riz AM, Popkin BM. Trends in energy intake in U.S. between 1977 and 1996: similar shifts seen across age groups. Obes Res. 2002;10(5):370-378.

30. U.S. Department of Health and Human Services. Healthy People 2010. $2^{\text {nd }}$ ed. With Understanding and Improving Health and Objectives for Improving Health. Vol 2. Washington, DC: U.S. Government Printing Office, November 2000.

31. West Virginia Healthy People 2010 Objectives. Objective 19: Nutrition and Overweight. Available at: http://www.wvdhhr.org/bph/hp2010/objective/i.htm. Accessed August 4, 2003.

32. Centers for Disease Control and Prevention: Youth Risk Behavioral Surveillance System. 2003 State and Local Standard High School Questionnaire. Available at: http://www.cdc.gov/HealthyYouth/yrbs/index.htm. Accessed September 29, 2003.

33. CDC Growth Chart Training. www.cdc.gov/nudphp/dnpa/growthcharts/training/modules.

34. WIC Version Growth Charts from the WIC Learning Center. www.nal.usda.gov/wicworks/Learning_Center

35. Centers for Disease Control and Prevention: Nutrition and physical activity: BMI for children and teens. Available at: http://www.cdc.gov/nccdphp/dnpa//bmi/bmi-forage.htm. Accessed April 25, 2004.

36. Krummel DA, Farmer, JL, Semmens ET. West Virginia Eating Activity Teen Survey (WVEATS) Final Report. Submitted to: the West Virginia Bureau for Public Health. January 15, 2004.

37. Abbott Hess M, Portion Photos of Popular Foods. The American Dietetic Association and Center for Nutrition Education University of Wisconsin-Stout. 1997. 
38. Food Labeling. Code of Federal Regulations. Food and Drug Administration. Department of Health and Human Services. Available at: http://www.cfsan.fda.gov/ 1rd/CF101-12.html. Accessed May 1, 2004.

39. Neumark-Sztainer D, Hannan PJ, Story M, Croll J, Perry C. Family meal patterns: Associations with sociodemographic characteristics and improved dietary intake among adolescents. J Am Diet Assoc. 2003;103:1015-1019.

40. Nelson M, Bingham SA. Assessment of food consumption and nutrient intake. In: Margetts BM, Nelson M, eds. Design Concepts in Nutritional Epidemiology. $2^{\text {nd }}$ ed. New York, NY: Oxford University Press; 1997.

41. Subcommittee on Interpretation and Uses of Dietary Reference Intakes and the Standing Committee on the Scientific Evaluation of Dietary Reference Intakes. Dietary Reference Intakes. Applications in Dietary Planning. Food and Nutrition Board. Institute of Medicine Washington DC: National Academy of Press, 2003.

42. Subcommittee on Interpretation and Uses of Dietary Reference Intakes and the Standing Committee on the Scientific Evaluation of Dietary Reference Intakes. Dietary Reference Intakes. Applications in Dietary Assessment. Food and Nutrition Board. Institute of Medicine. Washington DC: National Academy of Press, 2000.

43. Arab L, Carriquiry A, Steck-Scott S, Gaudet MM. Ethnic differences in nutrient intake adequacy of premenopausal US women: results from the Third National Health Examination Survey. J Am Diet Assoc. 2003;103:1008-1014. 
APPENDICES 
APPENDIX A 
Dear Superintendent:

The WVU School of Medicine is working with the West Virginia Bureau for Public Health to conduct a research project entitled the West Virginia Eating Activity Teen Survey (WVEATS). The goal of WVEATS is to learn about diet and physical activity behaviors among high school students. This data is being collected for WV Healthy People 2010, the state's health objectives.

You can assist WVEATS by allowing us to visit your county high schools during the 2002-2003 school year. The participating students from your school(s) will be interviewed by a dietitian for less than 30 minutes on their diet, activity, and health patterns during school hours.

The data will be kept confidential per Institutional Review Board protocol. The study received Institutional Review Board approval on April 24, 2002. Thus, names will not used on surveys, only numbers. To qualify, the students must be WV residents attending a WV public school, and they must obtain written consent from their parent(s) or guardian.

We hope you will find this study a good opportunity for your county schools. If you concur, we will need an official letter of support, on your letterhead, mailed to the address below. Please refer to the enclosed flier for additional information. If you have any questions regarding the study, please feel free to call me at (304) 293-1824. If you have questions regarding the participation of your county school(s), please contact the study coordinator, Jennifer Farmer, at (304) 293-0224.

Sincerely yours,

Debra Kummel, PhD, RD

WVEATS Principal Investigator

Enclosure

8701 Health Sciences South PO Box 9190 Morgantown WV 26506-9190 Telephone 304 293-0224 FAX 304 293-4754

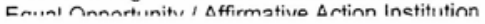


December 10, 2002

APPROVEO

Dear Principal:

We need your help! The WVU School of Medicine is working with the West Virginia Bureau for Public Health to conduct a research project entitled the West Virginia Eating Activity Teen Survey (WVEATS). The goal of WVEATS is to learn about diet and physical activity behaviors among high school students. The data is being collected for WV Healthy People 2010, the state's health objectives.

We invite your school to be a part of WVEATS. The participating students will be interviewed by a dietician for less than 30 minutes. The data will be kept confidential per WVU Institutional Review Board protocol. The study received Institutional Review Board approval on April 24, 2002. Thus, names are not used on surveys, only numbers.

Our goal is to interview 1000 students for the 2002-2003 school year. If you choose to participate, we will need an official letter of support, on school letterhead, mailed to the address below. Please post the enclosed flier on your student bulletin board or forward it to your health and physical education teachers.

We hope you will find this study a good opportunity for your students to learn more about their nutrition and physical activity behaviors. If you have questions regarding the methodology of the study, feel free to call me at (304) 293-1824. If you have questions regarding the participation of your school, please contact the study coordinator, Jennifer Farmer, at (304) 293-0224.

Sincerely yours,

Debra Krummel, PhD, RD

WVEATS Principal Investigator

Enclosure 


\section{W. Community Medicine}

WEST VIRGINIA UNIVERSITY " Institution Review Board for the Protection of Human Research Subjects

December 10, 2002

FFB 102003

$x$

DEROVFn

EXPIRES
H.S. $\#$

Dear Teacher:

We need your help! The WVU School of Medicine is working with the West Virginia Bureau for Public Health to conduct a research project entitled the West Virginia Eating Activity Teen Survey (WVEATS). The goal of WVEATS is to learn about diet and physical activity behaviors among high school students. These data are being collected for WV Healthy People 2010, the state's health objectives.

WVEATS is a free study for WV public high school students. The participating students will be interviewed individually for less than 30 minutes. At each school, we will be working with several teachers to release students for the interviews.

The data will be kept confidential per Institutional Review Board protocol. The study received Institutional Review Board approval on April 24, 2002. Thus, names are not used on surveys, only numbers.

If you would like your students to participate and receive the results of the dietary analysis for a class project, please let us know.

In the 2002-2003 school year, we will be interviewing $1000 \mathrm{WV}$ students. If you would like your class to participate, please call our study coordinator, Jennifer Farmer, at 304293-0224.

Sincerely yours,

Debra Krummel, PhD, RD

WVEATS Principal Investigator

Enclosure

8701 Health Sciences South PO Box 9190 Morgantown WV 26506-9190 Telephone 304 293-0224 FAX 304 293-4754

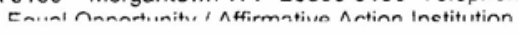




\section{Community Medicine}

WEST VIRGINIA UNIVERSITY

Institution Review Board for the "

Protection of Human Research Subjects

\begin{tabular}{ll} 
December 10, 2002 & \multicolumn{1}{c}{ APPROVER } \\
& $\begin{array}{l}\text { EXPIKES } \\
\text { H.S. \# }\end{array}$ \\
&
\end{tabular}

Dear Parents:

The WVU School of Medicine is working with the West Virginia Bureau for Public Health to conduct a research project entitled West Virginia Eating Activity Teen Survey

(WVEATS). The overall goal of WVEATS is to learn about diet and physical activity behaviors in high school students.

We are collecting this data as baseline information for the state of West Virginia as part of the Healthy People 2010 objectives on nutrition and physical activity. Our goal is to interview 1000 West Virginia students. High schools will be enrolled on a first-come, first-served basis.

The participating students will be interviewed for 30 minutes on their diet and activity behaviors. We will work with staff and teachers to schedule the interviews. The diet analysis is being used for a project in some classes. Attached to this letter is a consent form, which you must complete for your teen to be able to participate. Once consent is obtained, the students can be interviewed.

All data from the study is kept confidential. If you would like your teen to participate, please sign the attached consent form and return to us in the attached self-addressed stamped envelope, or through your teen. If you have any questions, please contact our study coordinator, Jennifer Farmer (304-293-0224 or jfarmer@hsc.wvu.edu), or me (304-293-1824 or dkrummel@hsc.wvu.edu). We look forward to working with your son or daughter.

Thank you for your assistance with WVEATS.

Sincerely yours,

Debra Krummel, PhD, RD

WVEATS Principal Investigator 


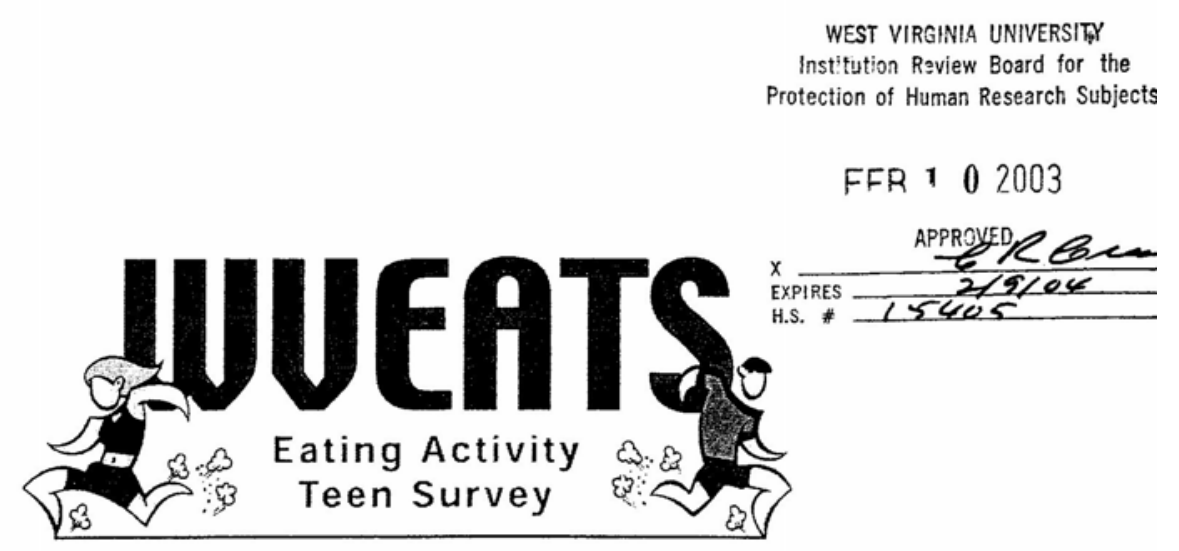

Attention high school students: We want you...

- To participate in a research survey and interview on diet and activity

- To help the state collect diet and physical activity data on teens

Get a free diet analysis and enter a raffle for prizes.

It only takes a half hour.

If you want to participate, see your health or physical education teacher for more information.

WVU-Department of Community Medicine

Dr. Debra Krummel, 304-293-1824

Jennifer Farmer, 304-293-0224 


\section{WVEATS FACT SHEET}

\section{WVEATS is ....}

- the WVEating Activity Teen Survey;

- a study that will help us to learn about eating and activity;

- sponsored by the West Virginia Bureau for Public Health;

- conducted by West Virginia University (Dr. Debra Krummel, PI); and

- FREE.

\section{What will I have to do?}

- Complete a 30 minute interview with a dietitian on your diet and activity behaviors. Interviews will be held at school during school hours.

\section{What are the benefits?}

- Being a part of the state data on Healthy People 2010 goals.

- Receiving a free nutrition and physical activity analysis.

- Being eligible for prizes.

\section{Does the WVEATS study affect my grades?}

- No, WVEATS will not affect any grades.

\section{Will anyone have access to my information?}

- No, your answers are confidential and will not be released to anyone not involved with the study.

\section{Who can participate?}

- Any high school student attending a WV High School.

For more information, please contact Jennifer Farmer, WVEATS Coordinator, 304-2930224.

$(9 / 27 / 02)$

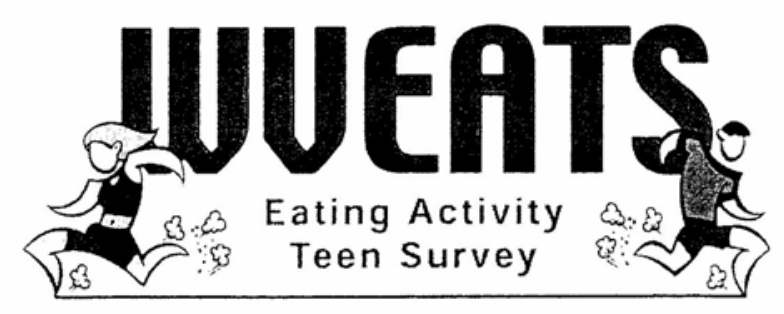




\section{Community Medicine ROBERT C. BYRD HEALTH SCIENCES CENTER} The West Virginia Eating Activity Teen Survey (WVEATS) Parental Consent Form

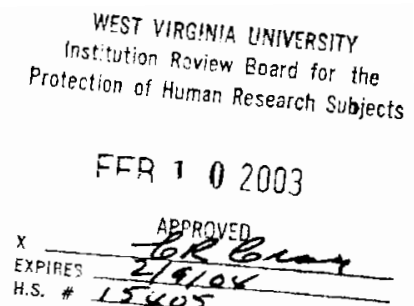

Introduction. I , have been asked to allow my teen, to participate in this research study. Debra Krummel, PhD at West Virginia University, is conducting this study. Funding is being provided by the WV Bureau of Public Health.

Purpose of the Study. The purpose of the study is to learn more about the eating habits and activity patterns of teenagers.

Description of Procedures. Data collection for WVEATS will occur at my child's high school during school hours and will involve completing a survey and a diet interview. The survey contains diet, physical activity, and health pattern questions. Attached is a copy of the survey questions. In the diet interview, dietitians will ask students to recall what foods they ate in the past 24 hours and measure their height and weight. The total study population will be $1000 \mathrm{WV}$ high school students.

Benefits. There will be no direct benefits to my child for participating in the study. However, participants will be contributing to the state data for Healthy People 2010 goals. Also, the knowledge gained from this study may be used to help develop programs on nutrition and physical activity for teens.

Financial Considerations. Participants will be entered into a raffle for prizes $(\$ 15$ to $\$ 100$ ).

Risks and Discomforts. There are no known or expected risks or discomforts from participating in this study.

Confidentiality. All of the students' data will be coded by number and kept as confidential as legally possible. Only the research team will have access to the data.

Contact Persons. For more information about this research, I may contact Jennifer Farmer at 304-293-0224 or Dr.Debra Krummel at 304-293-1824. For information about my child's rights as a research subject, I may contact the Executive Secretary of the Institutional Review Board at 304-293-7073.

Voluntary Participation. Participation in this study is voluntary. I understand that I may withdraw my child from this study at any time. Refusal to participate or withdrawal will have no effect on his/her grades or class standing, nor will there be any other penalty or loss of benefits for my child or me. I have been given the opportunity to ask questions about the research, and 1 have received answers concerning areas I did not understand. Upon signing this form, I will receive a copy. I willingly consent to my child's participation in this study.

Signature of Minor's Parent or Guardian

$\overline{\text { Date }} \overline{\text { Time }}$

Signature of investigator or Representative

Date Time

$09 / 27 / 02$

8701 Health Sciences South PO Box 9190 Morgantown WV 26506-9190 Telephone 304 293-0224 FAX 304 293-4754 Equal Opportunity / Affimative Action Institution, Version 1 


\section{PARENTAL NOTIFICATION FORM \\ WEST VIRGINIA EATING ACTIVITY TEEN SURVEY (WVEATS)}

\section{Dear Parents:}

Your son/daughter will have either a Physical Education or Health Education class during this semester that will be involved in a WVU research project. The WVU School of Medicine is conducting the project entitled West Virginia Eating Activity Teen Survey (WVEATS) during your child's class session. The overall goal of WVEATS is to learn about diet and physical activity behaviors among high school students.

The data being collected will be the baseline information for the state of West Virginia as part of the Healthy People 2010 objectives on nutrition and physical activity. The participating students will complete a survey and a diet interview. The survey contains diet, physical activity, and health pattern questions. In the diet interview, nutritionists will ask students to recall what foods they ate or drank in the past 24 hours and then measure their height and weight. Participating students will also be entered into a raffle for prizes valued $\$ 15$ to $\$ 100$.

There are no known or expected risks or discomforts for students participating in this study. However, at any time during the study, if your child feels uncomfortable he/she can remove himself from the study or choose to simply not answer a question. All of the students' data will be coded by number and kept as confidential as legally possible. Only the research team will have access to the data.

Please understand that as a parent or guardian, you have the right to exclude your child from the WVEATS research study. If you wish to exercise this right, complete the bottom portion of this form and return it to the school within five (5) days. Your child will not be penalized for nonparticipation in WVEATS.

For more information or questions relating to the research project and its process contact Jennifer Farmer at 304-293-0224, Dr. Debra Krummel at 304-293-1824, or Jenni Jones at 304-346-5198. For more information about your child's right as a research subject you may contact the Executive Secretary of the Institutional Review Board at 304-293-7073.

Sincerely,

The WVEATS Research Team

\section{PLEASE COMPLETE THE FORM BELOW AND RETURN WITHIN FIVE DAYS.}

I do not want my child,
the WVEATS research project this year at
Parent/Guardian Signature
$\begin{aligned} & \text { Please understand that this form must be returned or your child will participate in the } \\ & \text { WVEATS research project. }\end{aligned}$


APPENDIX B 


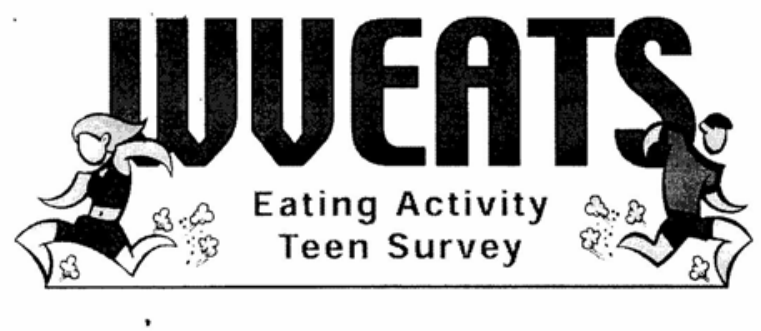

ID \#

\section{Please answer these questions as honestly as possible. Remember, all of your answers are private.}

\section{Please check only 1 answer.}

1. When were you born? (Month, Day and Year)

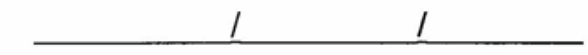

2. What is your gender?
A. Male
B. Female

3. Do you think of yourself as:
A. White
B. Black or African American
C. Hispanic or Latino
D. Asian American
E. Hawaiian or Pacific Islander
F. American Indian or Alaska Native

4. What is the highest level of education that your mother completed?
A. $11^{\text {th }}$ grade or less
B. High school or GED
C. Some college
D. Vocational, technical or associate degree
E. College degree
F. Master's or doctoral degree
G. Don't know 


\section{Please check only 1 answer.}

5. What is the highest level of education that your father completed?
A. $11^{\text {th }}$ grade or less
B. High school or GED
C. Some college
D. Vocational, technical or associate degree
E. College degree
F. Master's or doctoral degree
G. Don't know

6. Does your family qualify for free or discounted school breakfast or lunch, WIC or other public assistance?
A. Yes
B. No
C. Don't know

7. Is your mother employed:
A. Full-time
B. Part-time
C. Not employed
D. Don't know
E. Other

8. Is your father employed:
A. Full-time
B. Part-time
C. Not employed
D. Don't know
E. Other

9. In what grade are you?
A. 9th grade
B. 10th grade
C. 11th grade
D. 12th grade

10. What is your grade point average in high school?
A. $<1.5$
B. 1.6 to 2.5
C. 2.6 to 3.0
D. 3.1 to 3.5
E. $>3.6$
F. don't know 


\section{Please check only 1 answer.}

11. How tall are you?

feet inches

12. How much do you weigh?

Ibs

The next 5 questions ask about body weight.

13. How do you describe your weight?
A. Very underweight
B. Slightly underweight
C. About the right weight
D. Slightly overweight
E. Very overweight

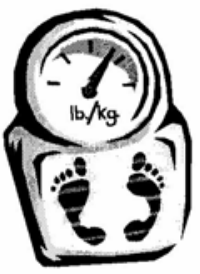

14. Which of the following are you trying to do about your weight?
A. Lose weight
B. Gain weight
C. Stay the same weight
D. I am not trying to do anything about my weight

15. During the past 30 days, did you exercise to lose weight or to keep from gaining weight?
A. Yes
B. No

16. During the past 30 days, did you eat less food, fewer calories, or foods low in fat to lose weight or to keep from gaining weight?
A. Yes
B. No

17. During the past $\mathbf{3 0}$ days, did you go without eating for $\mathbf{2 4}$ hours or more (also called fasting) to lose weight or to keep from gaining weight?
A. Yes
B. No

Please Go To The Next Page 


\section{Please check only 1 answer.}

Think about what you normally eat when you answer the next 9 questions.

18. How often do you drink $100 \%$ fruit juices such as orange juice, apple juice, or grape juice?

(Do not count punch, Kool-Aid, sports drinks, or other fruit-flavored drinks.)
A. never
B. less than once a WEEK
C. $1-3$ times a WEEK
D. 4-6 times a WEEK
E. once a DAY
F. 2 times a DAY
G. 3 or more times a DAY

19. How often do you eat fruit?

(Include fresh, canned, cooked or dried fruits)
A. never
B. less than once a WEEK
C. $1-3$ times a WEEK
D. $4-6$ times a WEEK
E. once a DAY
F. 2 times a DAY
G. 3 or more times a DAY

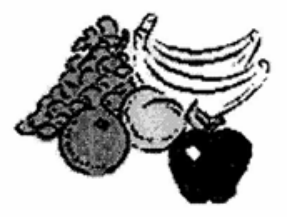

20. How often do you eat green salad, like lettuce or spinach salad?
A. never
B. less than once a WEEK
C. 1 - 3 times a WEEK
D. 4-6 times a WEEK
E. once a DAY
F. 2 times a DAY
G. 3 or more times a DAY

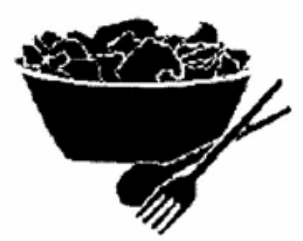

21. How often do you eat French fries, fried potatoes or hash browns?
A. never
B. less than once a WEEK
C. $1-3$ times a WEEK
D. $4-6$ times a WEEK
E. once a DAY
F. 2 times a DAY
G. 3 or more times a DAY

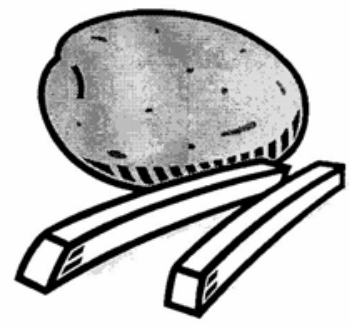

Please Go To The Next Page 


\section{Please check only 1 answer.}

22. How often do you eat baked, boiled or mashed potatoes?
A. never
B. less than once a WEEK
C. 1 - 3 times a WEEK
D. 4- 6 times a WEEK
E. once a DAY
F. 2 times a DAY
G. 3 or more times a DAY

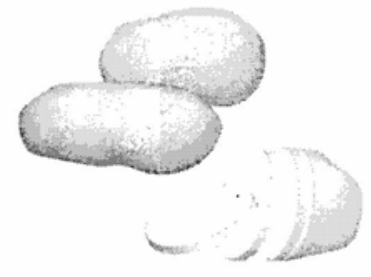

23. How often do you eat vegetables? (Include all kinds-fresh, canned and cooked)
A. never
B. less than once a WEEK
C. $1-3$ times a WEEK
D. $4-6$ times a WEEK
E. once a DAY
F. 2 times a DAY
G. 3 or more times a DAY

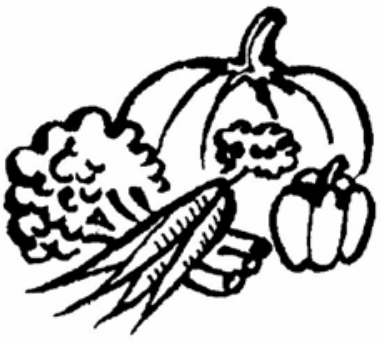

24. How often do you eat beans like baked beans, red beans, or black-eyed peas? (Include beans in chili, bean soup and beans and rice)
A. never
B. less than once a WEEK
C. $1-3$ times a WEEK
D. $4-6$ times a WEEK
E. once a DAY
F. 2 times a DAY
G. 3 or more times a DAY

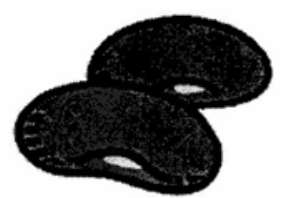

25. How many glasses of milk did you drink?

(Include the milk you drank in a glass or cup, from a carton, or with cereal. Count the half pint of milk served at school as equal to one glass.)
A. Never
B. less than once a WEEK
C. 1 - 3 times a WEEK
D. 4- 6 times a WEEK
E. once a DAY
F. 2 times a DAY
G. 3 or more times a DAY

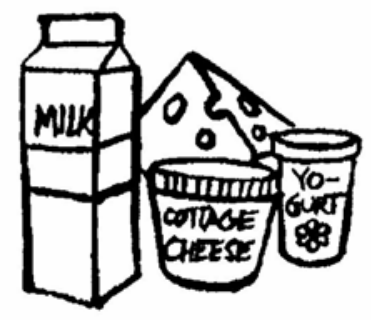




\section{Please check only 1 answer.}

26. How many servings of fruits and vegetables do you eat in a day?

( 1 serving of vegetables are: 1 cup of raw leafy vegetables; $1 / 2$ cup of other vegetables, cooked or chopped raw; $3 / 4$ cup of vegetable juice)

( 1 serving of fruit is: 1 medium apple, orange, banana; $1 / 2$ cup of chopped, cooked or canned fruit; $3 / 4$ cup of fruit juice)
A. $0-1$
B. $2-4$
C. 5 or more

27. How many times each week (including weekdays and weekends) do you eat breakfast?
A. Never
B. 1-2 times per week
C. 3-4 times per week
D. 5 or more times per week

28. How sure are you that you could eat breakfast every day if you wanted to?
A. extremely sure (I already do it)
B. very sure
C. somewhat sure
D. slightly sure
E. not sure

29. How sure are you that you could eat at least five servings of fruits and/or vegetables each day?
A. extremely sure (I already do it)
B. very sure
C. somewhat sure
D. slightly sure
E. not sure

30. Which are the reasons that you do not eat more fruits or vegetables? Check all that apply.
A. other foods taste better than fruits and/or vegetables
B. there are not many fruits and/or vegetables at my house
C. I do not have time to fix fruits and/or vegetables
D. I do not eat fruits and/or vegetables because of how they look
E. none of my friends eat fruits and/or vegetables 


\section{Please check only 1 answer.}

\section{The next 6 questions are about chronic diseases.}

31. Which of the following would be helpful if a person wanted to reduce their risk of developing osteoporosis? Circle all that apply.
A. Eating enough calcium-rich foods
B. Having enough vitamin D from the diet and/or sunlight
C. Being more active
D. Taking estrogen or hormone replacement therapy if a woman is post- menopausal
E. Using sugar only in moderation
F. Taking calcium supplements
G. I do not know what osteoporosis is
$\mathrm{H}$. I do not know what affects osteoporosis

32. Have you ever been told by a doctor that you had asthma?
A. Yes
B. No
C. Don't know or Not sure

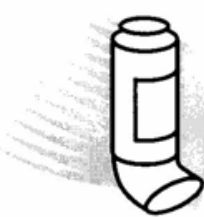

33. Symptoms of asthma include cough, wheezing, shortness of breath, chest tightness and phlegm production in the absence of a cold or respiratory infection.

During the past 4 weeks, how often did you have symptoms of asthma?
A. Never (no symptoms in the past 4 weeks)
B. Less than once a week
C. Once or twice a week
D. More than 2 times a week, but not every day
E. Every day, but not all the time
F. Everyday, all the time
G. Don't know

34. Have you ever been told by a doctor that you have diabetes?
A. Yes
B. Yes, but female told only during pregnancy
C. No
D. Don't know/not sure
E. Refused

35. Have you had a sunburn within the past 12 months?
A. Yes
B. No (Go to next section)
C. Don't know/not sure
D. Refused

Please Go To The Next Page 


\section{Please check only 1 answer.}

36. Including the times when even a small part of your skin was red for more than 12 hours, how many sunburns have you had within the past 12 months?
A. One
B. Two
C. Three
D. Four
E. Five
F. Six or more
G. Don't know/not sure
H. Refused

The next 7 questions ask about physical activity.

37. On how many of the past 7 days did you exercise or participate in physical activity for at least $\mathbf{2 0}$ minutes that made you sweat and breathe hard, such as basketball, soccer, running, swimming laps, fast bicycling, fast dancing, or similar aerobic activities?
A. 0 days
B. 1 day
C. 2 days
D. 3 days
E. 4 days
F. 5 days
G. 6 days
H. 7 days

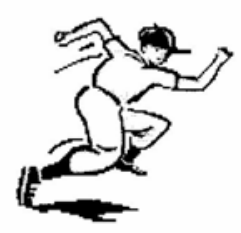

38. On how many of the past 7 days did you participate in physical activity for at least 30 minutes that did not make you sweat or breathe hard, such as fast walking, slow bicycling, skating, pushing a lawn mower, or mopping floors?
A. 0 days
B. 1 day
C. 2 days
D. 3 days
E. 4 days
F. 5 days
G. 6 days
H. 7 days

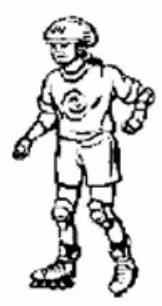

Please Go To The Next Page 


\section{Please check only 1 answer.}

39. On how many of the past 7 days did you do exercises to strengthen or tone your muscles, such as push-ups, sit-ups, or weight lifting?
A. 0 days
B. 1 day
C. 2 days
D. 3 days
E. 4 days
F. 5 days
G. 6 days
H. 7 days

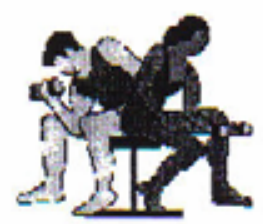

40. On an average school day, how many hours do you watch TV?
A. I do not watch TV on an average school day
B. Less than 1 hour per day
C. 1 hour per day
D. 2 hours per day
E. 3 hours per day
F. 4 hours per day
G. 5 or more hours per day

41. In an average week when you are in school, on how many days do you go to physical education (PE) classes?
A. 0 days
B. 1 day
C. 2 days
D. 3 days
E. 4 days
F. 5 days

42. During an average physical education (PE) class, how many minutes do you spend actually exercising or playing sports?
A. I do not take PE
B. Less than 10 minutes
C. 10 to 20 minutes
D. 21 to 30 minutes
E. 31 to 40 minutes
F. 41 to 50 minutes
G. 51 to 60 minutes
$\mathrm{H}$. More than 60 minutes

Please Go To The Next Page 
Please check only 1 answer.

43. During the past 12 months, on how many sports teams did you play? (Include any teams run by your school or community groups.)
A. 0 teams
B. 1 team
C. 2 teams
D. 3 or more teams

\section{Thank you for participating in WVEATS.} $11 / 21 / 02$

For Office Use Only:

HT:

WT: 
APPENDIX C 
CDC Growth Charts: United States

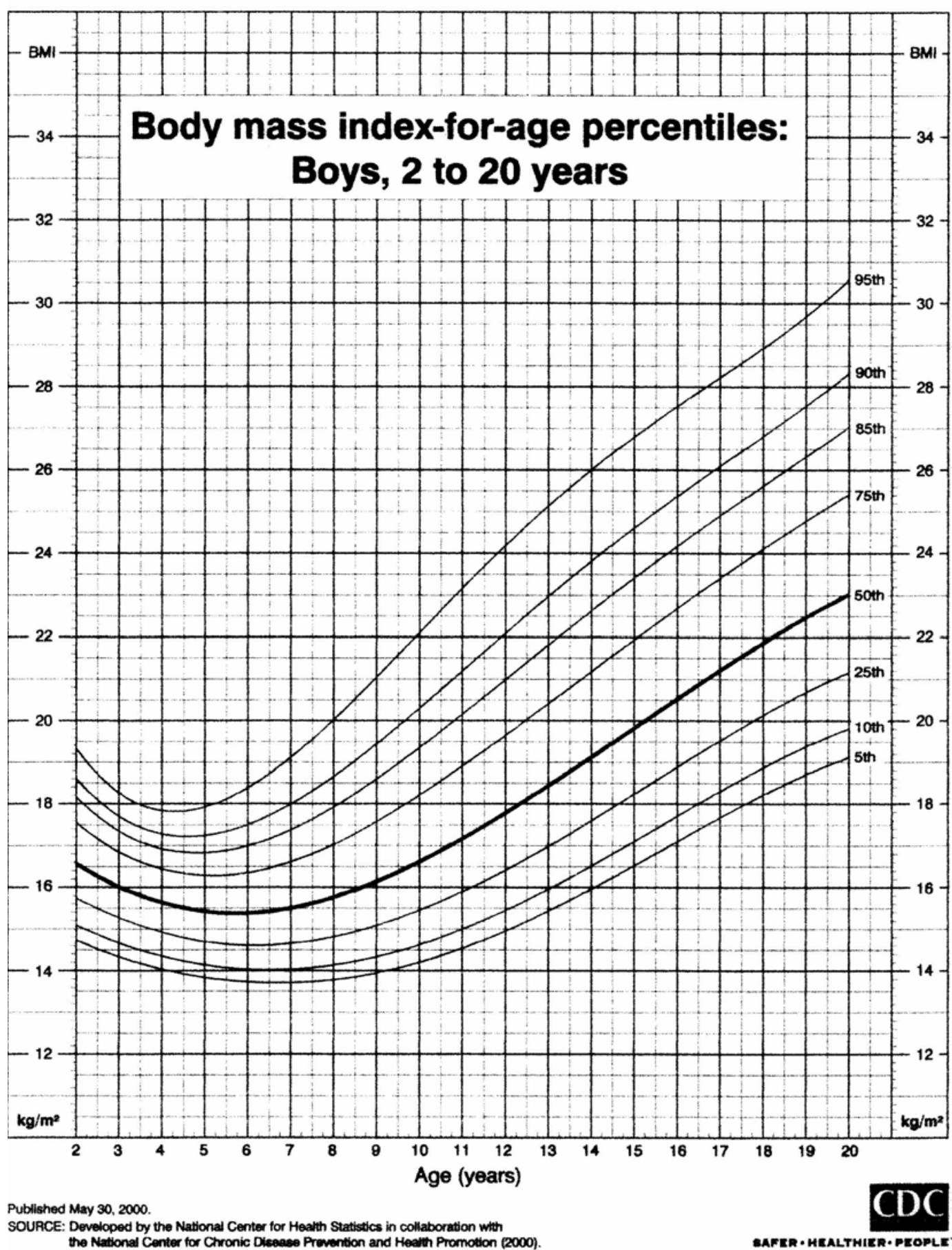


CDC Growth Charts: United States

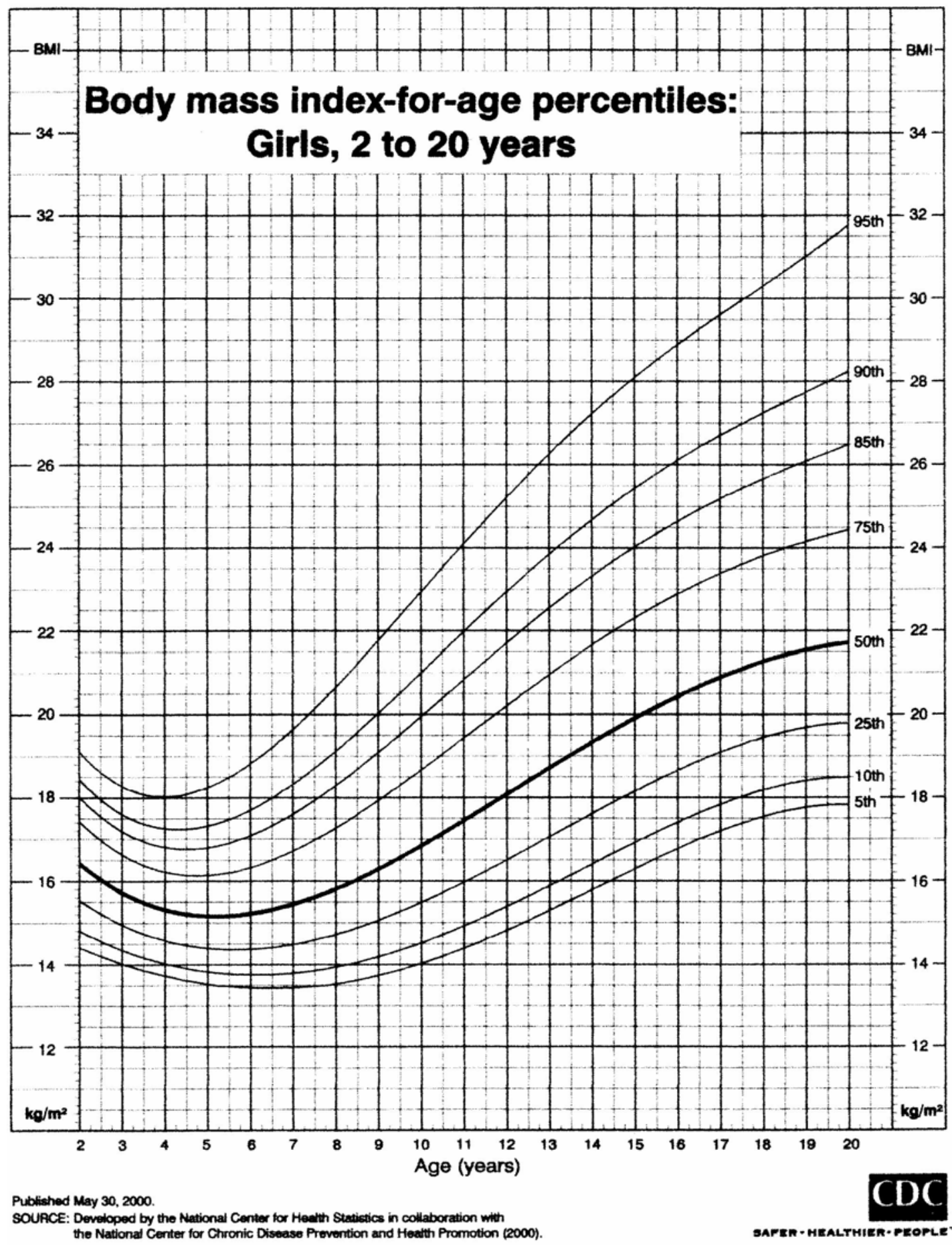


APPENDIX D 


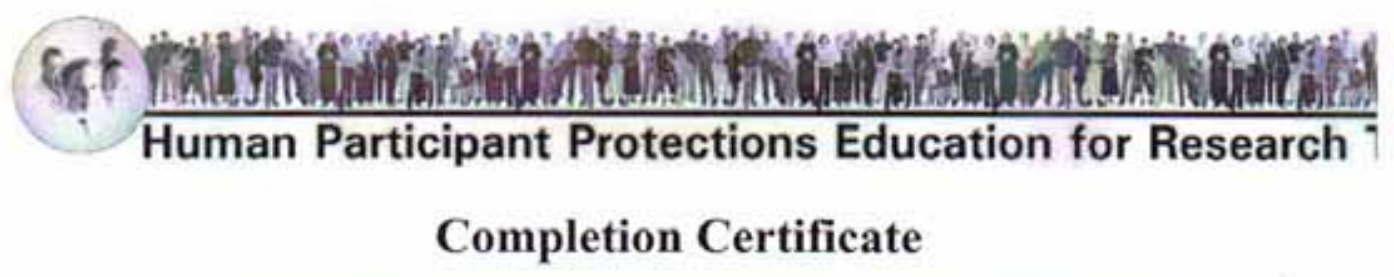

This is to certify that

\section{Kimberly Morris}

has completed the Human Participants Protection Education for Research Teams online course, sponsored by the National Institutes of Health (NIH), on 09/17/2003.

This course included the following:

- key historical events and current issues that impact guidelines and legislation on human participant protection in research.

- ethical principles and guidelines that should assist in resolving the ethical issues inherent in the conduct of research with human participants.

- the use of key ethical principles and federal regulations to protect human participants at various stages in the research process.

- a description of guidelines for the protection of special populations in research.

- a definition of informed consent and components necessary for a valid consent.

- a description of the role of the IRB in the research process.

- the roles, responsibilities, and interactions of federal agencies, institutions, and researchers in conducting research with human participants.

National Institutes of Health http://www.nih.gov 


\section{VITA}

\section{Kimberly M. Morris}

Morgantown, WV 26508

kmorris7@mix.wvu.edu

\section{$\underline{\text { Education }}$}

- RD eligible through ADA Dietetic Internship program at West Virginia University

- M.S. degree in Human Nutrition and Foods from West Virginia University; in progress with overall G.P.A. of 3.6 and expected graduation date of August 2004

- B.S. in Family and Consumer Sciences with an emphasis in Human Nutrition and Foods from West Virginia University: graduated Cum Laude; May 1998.

\section{Professional Experiences}

Graduate Assistant with the West Virginia University State Extension Agency: March 2004- current

- Specializing in diabetes education and program development for the state

Graduate Teaching Assistant while attending West Virginia University: September 2002- June 2003

- Maintained records and assisted in the development of educational materials

- Substitute lecturer for nutrition class with over 100 collegiate level students

Public Health Nutritionist I \& II for the Allegheny County WIC Program in Pittsburgh, PA: January 2000 to August 2002

Nutrition Education *Received certificates of appreciation (9/00 \& 3/02) and outreach award (3/02)

- Assessed nutritional risk and provided education, referrals, and dietary services for 'high risk' pregnant women, infants, and children

- Collaborated with social service organizations and volunteered for local community projects to provide nutrition education to teen parents and elementary school students

Clinical Management *Received office awards for 'team work' and achievement (3/02)

- Managed all new enrollment and recertification procedures in clinic with case load of over 700 clientele per month

- Supervised employees, trained new staff, and oversaw office operations for two sites

- Produced monthly, quarterly, and annual reports and controlled inventory, educational materials, and all federal, state, and local policies for clinic site 


\section{Kimberly M. Morris}

Page 2

\section{Computer Skills}

- DOS, Windows 98', 00’, and XP systems, Microsoft Office programs, etc.

- Nutritional analysis software programs: West Diet Analysis, Nutritionist 4, Eat Right Analysis, ESHA Diet Analysis Plus, and The Food Processor

\section{Publications}

- Authored two articles for the Morgantown, WV Dominion Post, appearing October 2003

- Co-authored two nutrition education pamphlets for state extension program in West Virginia, developed in 2003, circulated state-wide in 2004

\section{Professional Memberships}

- The American Dietetic Association

- West Virginia Dietetic Association

- Diabetes Care and Education - ADA affiliated dietetic practice group

- Nutrition Education for the Public - ADA affiliated dietetic practice group 